\title{
Inwektywy czasów II wojny światowej. Językowe środki obrażania przeciwnika/ wroga politycznego w prasie konspiracyjnej lat 1939-1945
}

\section{Abstrakt}

$\mathrm{W}$ artykule przedstawiono strategie deprecjonowania przeciwnika politycznego na materiale prasy konspiracyjnej, wydawanej w okupowanej Polsce w latach 1939-1945. Okazuje się, że język propagandy politycznej opisywanego okresu politycznego zawierał wiele strategii komunikacyjnych służących do walki z rywalem politycznym, niejednokrotnie utożsamianym $\mathrm{z}$ wrogiem. $\mathrm{W}$ artykule pokazano więc przykłady wykorzystywania inwektywy politycznej w bardzo ważnym okresie walki o władzę między ugrupowaniami politycznymi działającymi w podziemiu (konspiracji).

Słowa kluczowe: wojenny dyskurs polityczny, propaganda polityczna, propaganda wojenna, język propagandy politycznej okresu II wojny światowej, inwektywa polityczna.

\section{Ustalenia wstępne i cele badawcze}

Artykuł rozpocznę od kilku porządkujących uwag metodologicznych. Przedmiotem moich rozważań — o czym komunikuje tytuł — jest opis inwektyw politycznych (aktów agresji słownej), które pojawiły się w konspiracyjnych tekstach propagandowych okresu II wojny światowej i służyły deprecjacji wroga/przeciwnika politycznego. To czas, w którym komunikacja polityczna została podporządkowana sytuacji walki zbrojnej, a język polityki — odbijający brutalną rzeczywistość — w sposób nacecho- 
wany wprowadzał dychotomiczne podziały na „swoich” i „obcych” („wrogów”). Akty komunikacji perswazyjnej w badanym okresie służyły przede wszystkim mobilizacji społeczeństwa do walki z wrogiem (okupantem), agresorem i rzeczywistym podmiotem antagonistycznych relacji, działań zbrojnych (także sabotażowo-dywersyjnych) i uczuć nienawiści (por. Wolińska 1992, 1996). Niemniej na tle dominującej retoryki, sięgającej często po hasła, mity, toposy o rodowodzie romantycznym i niepodległościowym, pojawiały się burzliwie polemiki z przeciwnikiem ideowym, przybierające postać inwektywy lub aktów agresji werbalnej.

$\mathrm{W}$ artykule rezygnuję z opisu strategii propagandowych kształtujących obraz władz hitlerowskich i nazistowskiego totalitaryzmu, gdyż w tym wypadku wróg - jak pisze Olga Wolińska - „nie był figurą stylistyczną, był realny, dotkliwy” (Wolińska 1996: 343). Przedstawiam zaś strategie deprecjacji przeciwnika politycznego, które nadawały charakter polemikom politycznym okresu wojennego, wykorzystywane były przez ugrupowania polityczne w ich działalności propagandowej związanej z walką o władzę (jej legitymizację lub delegitymizację). Niejednokrotnie ujawniała się w nich agresja językowa, a na poziomie kreacji obrazu przeciwnika/ rywala politycznego dominowała kategoria „wroga wewnętrznego”, która zawierała językową konceptualizację „zwalczanych ideologii, poglądów, postaw, zachowan”” (Kamińska-Szmaj 2007: 62).

W czasie wojny zachwiany został cały porządek polityczny II Rzeczypospolitej, a nowa, podziemna scena polityczna kształtowała się w atmosferze burzliwych polemik, oskarżeń o zdradę, antagonistycznych podziałów. Niektóre z nich były konsekwencją niedomkniętych sporów ideologicznych dwudziestolecia międzywojennego (zob. Kamińska-Szmaj 1994, 2007; Polkowska 2015), tym samym wnosiły do języka polityki lat 1939-1945 dawniejsze uprzedzenia w nowych kontekstach znaczeniowych - inne zaś, osadzone w podziałach politycznych okresu okupacyjnego, pojawiły się w nowej odsłonie pod koniec wojny (1944 rok) jako podstawa języka propagandy politycznej „władzy ludowej” (a potem PRL-u) (zob. między innymi Nowak 2002; Kamińska-Szmaj 2014, 2015; Ożóg 2014). Co więcej, w okresie okupacji wyłaniały się kolektywne symbole późniejszych (także współczesnych) dyskursów, określanych przez Katarzynę Kłosińską (2012) jako „etyczny i pragmatyczny”, a niekiedy etykietki językowe, które swą intertekstualną/konotacyjną ekspozycję odnalazły w późniejszych walkach na słowa, w różnych powojennych typach komunikacji politycznej (zob. Kamińska-Szmaj 2007; Zimny, Nowak 2009; Nowak 2002; Dytman-Stasieńko 2006; Chrobaczyński 2015).

Język polityki lat 1939-1945, chociaż niezwykle ciekawy z tego powodu, że przecinały się w nim różne odmiany komunikacji propagandowej (pluralistyczna vs. totalitarna; jawna vs. niejawna; LTI vs. nowomowa), wciąż wymaga pogłębionych studiów na tle niezwykle bogatego dorobku z zakresu współczesnej politolingwisty- 
$\mathrm{ki}^{1}$. Dlatego też przedstawiany artykuł powstał po części z potrzeby uzupełnienia tej luki badawczej.

Teksty i wypowiedzi, które analizuję, sytuują się na pograniczu propagandy wojennej i propagandy politycznej ${ }^{2}: z$ jednej strony nakłaniano za ich pomocą do oporu i walki, tworząc wspólnotę opartą na podobnych przeżyciach, doświadczeniach wojennych i wierze w zwycięstwo, z drugiej zaś - ustanawiały ramy podziemnego dyskursu społecznego (publicznego, obywatelskiego), a na poziomie odniesień do tematyki dyplomatycznej, ideologicznej, ustrojowej itp. stawały się podstawową ekspozycją rodzimego dyskursu politycznego. Przestrzenią tego dyskursu, a zarazem jego aktualizacją, była prasa konspiracyjna, którą tworzyły wszystkie ugrupowania polityczno-wojskowe Polski podziemnej. Materiał źródłowy został również wynotowany $\mathrm{z}$ tejże prasy, z artykułów politycznych, ideowych, propagandowych, reprezentujących różne, niekiedy skrajnie opozycyjne wobec siebie nurty polityczne, a jednocześnie obrazujących pluralistyczne (wielogłosowe) relacje między podmiotami (reprezentantami) sceny politycznej. Ponieważ przedstawiam w tym opracowaniu krótki zarys sytuacji politycznej, a także uproszczoną charakterystykę najważniejszych partii politycznych, rezygnuję ze szczegółowego omówienia oblicza ideowego gazet, z których zebrałem materiał językowy - w części badawczej istotne konteksty poprzedzam uwagami i komentarzami ${ }^{3}$.

Skupiając się na tekstach ideologiczno-propagandowych, odzwierciedlających cechy podziemnej kultury politycznej, rezygnuję z terminu język propagandy politycznej/język polityki na rzecz bardziej ogólnego terminu dyskurs polityczny. Wynika to bowiem $\mathrm{z}$ ugruntowanego już w polskiej lingwistyce statusu tego pojęcia — szczególnie na obszarze szeroko rozumianych badań politolingwistycznych (zob. Kamińska-Szmaj 2011, 2013; Małyska 2012; Kłosińska 2012), a ponadto z założenia, że kategoria dyskursu ujmuje komunikację polityczną w sposób holistyczny, to znaczy pozwala wyeksponować związek między językiem a aktywnością polityczną, między władzą a praktykami komunikacyjnymi, wreszcie — pozwala odsło-

${ }^{1} \mathrm{~W}$ tym opracowaniu wielokrotnie odwołuję się do wybranych prac poświęconych językowi polityki lat 1939-1945. Szczegółowy przegląd badań przedstawia I. Kamińska-Szmaj (2013: 417-419), zob. także I. Bajerowa (Język polski czasu... 1996).

2 Zob. przede wszystkim: U. Jarecka (2008), K. Stępnik i M. Rajewski (Komunikowanie się Polaków... 2011), A. Ignatowicz (2011), I. Kamińska-Szmaj (2013, 2014, 2015), O. Wolińska (1992, 1996), M. Mazur (2011).

${ }^{3}$ Analizowany materiał językowy został wyekscerpowany z prasy polityczno-ideowej różnych ugrupowań polityczno-wojskowych państwa podziemnego. Pochodzi z gazet wydawanych przez następujące środowiska (niektóre tytuły oznaczam skrótami): 1) Związek Walki Zbrojnej/Armię Krajową: „Biuletyn Informacyjny” - ZWZ/AK [BI]; 2) ugrupowania lewicy socjalistycznej, ludowej: „Robotnik” [Rob], wraz z mutacjami: „Robotnik w Walce”, „Robotnik WRN”, „Robotnik RPPS”, „Walka WRN”, „Gwardia Ludowa WRN”, „Kurier”, „Walka i Wolność”, „Barykada Wolności”, „Żywią i Bronią”; 3) partię komunistyczną (PPR) i środowiska lewicy radykalnej: „Wolna Polska” (ZPP) [WP], „Robotnik RPPS”, „Głos Warszawy” [Gł War], „Trybuna Wolności” [Tr Wol], „Rada Narodowa”; 4) ugrupowania narodowe (endeckie): „Walka”, „Głos Polski”, „Głos Ludu”; 5) środowiska skrajnej prawicy i narodowościowe: „Naród”, „Szaniec”. 
nić całokształt przekazów nacechowanych perswazyjnie na tle szerszego kontekstu społecznego, systemu władzy i dominującego „porządku dyskursu”4. Co więcej, w dyskursie odbija się wielokierunkowość komunikacji politycznej, jej wielogłosowy, wielopodmiotowy charakter, a zarazem zróżnicowany porządek aksjologiczny (ideologiczny), wyrażający retorykę polityczną, jak i pragmatyczny wymiar walki na słowa (perswazji politycznej). Na potrzeby tego opracowania odwołuję się do koncepcji dyskursu politycznego, którą zaproponowała Agata Małyska, pisząc:

Dyskurs polityczny odgrywa szczególną rolę w kształtowaniu rzeczywistości społecznej. Język jest instrumentem postrzegania i kreowania rzeczywistości [...]. Władza pełni kontrolę nad dyskursem i nadaje mu pożądany kierunek. Wypowiedzi zawarte $\mathrm{w}$ ramach dyskursu politycznego zawierają zwykle pewien element perswazyjny, są ukierunkowane na ustanowienie lub delegitymizowanie relacji władzy. (Małyska 2012: 73)

Trzeba dopowiedzieć, że komunikacja polityczna i propagandowa w Polsce pod okupacją niemiecką miała nietypowy wymiar dyskursywny. Władze hitlerowskie na części terytorium II Rzeczypospolitej utworzyły Generalne Gubernatorstwo (26 października 1939 roku), wprowadzając okupacyjny system prawny i własny system komunikacji masowej (medialnej). Miał on charakter totalitarny i był całkowicie podporządkowany niemieckiej polityce wojennej (okupacyjnej). Agresja niemiecka i stan okupacji naruszyły przedwojenny porządek polityczny, jednak władze polskie nie zrzekły się swych konstytucyjnych praw, nie zaakceptowały okupacji, kontynuowały swoje rządy na emigracji, ale już w nowej sytuacji polityczno-prawnej. Bezpośrednio po zakończeniu działań wojennych zaczęły się rozwijać struktury Polskiego Państwa Podziemnego (zob. Bartoszewski 1987; Chrobaczyński 2012, 2015; Szarota 1994 i inne). Tym samym w okupowanym kraju wyłoniły się dwa modele komunikacji politycznej. Po pierwsze, z oficjalnej przestrzeni komunikacyjnej zniknął pluralistyczny, wielogłosowy dyskurs polityczny oparty na prawie do wolności słowa i dwustronnych (sprzężonych) relacjach rządzący $\leftrightarrow$ rządzeni (por. Kamińska-Szmaj 2007) — w jego miejsce władze hitlerowskie wprowadziły totalitarny porządek władzy, nadając komunikacji politycznej monologową, jednostronną (hierarchiczną) relację okupujący $\rightarrow$ okupowani (zgodnie z polityką władz hitlerowskich, a sprzecznie z jurysdykcją polską, międzynarodową, a przede wszystkim legalną działalnością władz polskich na uchodźstwie) (por. Chrobaczyński 2015). Po drugie, w opozycji do władz hitlerowskich, a przede wszystkim na tle całej sytuacji wojennej i prawnej, wyłonił się podziemny dyskurs polityczny, wyrażający polską tożsamość polityczną oraz stanowiący praktykę sprawowania rządów w strukturach konspiracyjnych (wojskowych, politycznych, cywilnych). Najważniejsze właściwości tego dyskursu można by sprowadzić do kilku wyrazistych cech - uwzględniających charakter przekazu propagandowego, a także pozawerbalne mechanizmy kształtujące jego język. Posługując się na potrzeby tego opracowania

${ }^{4}$ Chodzi o kategorię spopularyzowaną dzięki koncepcjom dyskursu M. Foucaulta i P. Bourdieau - na ten temat miedzy innymi w: D. Howarth (2008), H. Grzmil-Tylutki (2011), zob. też B. Witosz (2009), M. Poprawa (2012) i inne. 
terminem podziemny dyskurs polityczny, przyjmuję, że jest to kategoria obejmująca takie zespoły zjawisk komunikacyjno-językowych, jak:

1) nielegalny, konspiracyjny (pod groźbą kary i represji) dyskurs polskich elit politycznych - obok ,legalnego", totalitarnego dyskursu okupanta (i w opozycji do tego dyskursu);

2) wykorzystujący mechanizmy perswazji (językowe środki nakłaniania), które prymarnie kształtowały wspólnotę zaangażowaną w walkę z okupantem lub bojkot/ kontestację okupanta, a sekundarnie były podstawowym narzędziem propagandy politycznej (walki o władzę);

3) dyskurs ten służy kontestacji świata wojennego, a także kreacji świata (niekiedy na poziomie funkcji apelatywnej) po zakończeniu działań zbrojnych, po odzyskaniu niepodległości, wolności;

4) mimo warunków konspiracyjnych zastępuje (również kontynuuje) przedwojenny dyskurs polityczny - w opozycji do hegemonicznego monologu propagandowego okupanta ma charakter wielogłosowy; jest podstawową sferą debaty publicznej i wielogłosowej polemiki politycznej, ideowej itp.;

5) ujawnia się w nim polaryzacja poglądów, wspólnot ideologicznych, a tym samym dychotomia MY-ONI - na tle wewnętrznych konfliktów przyjmuje ona postać nacechowanych deprecjonująco strategii zachowań językowych, a także aktów agresji słownej.

\section{Podziemny dyskurs polityczny — tożsamość ideologiczna, źródła napięć i konfliktów. Krótki zarys historyczny}

Władze polskie, działające po klęsce wrześniowej na emigracji — w 1939 roku w Paryżu, a od 1940 roku w Londynie ${ }^{5}$ - nie uznały okupacji (niemieckiej i rosyjskiej), a na mocy konwencji haskich z 1907 roku i międzynarodowego prawa wojennego działania militarne okupanta i narzucony przez niego porządek polityczny traktowały jako akt agresji (por. Chrobaczyński 2015; Bartoszewski 1987). Dzięki zapisom konstytucji kwietniowej z 1935 roku zachowała się ciągłość władzy, a rządy mogły być sprawowane w warunkach emigracyjnych, a co więcej, polskie władze na uchodźstwie zostały uznane przez dyplomację i społeczność międzynarodową. Reprezentacją władz polskich, działających od 1939 roku na uchodźstwie (a więc prezydenta, premiera, rządu, Rady Narodowej pełniącej funkcję parlamentu, naczelnego wodza, który dowodził polskimi siłami zbrojnymi, walczącymi w strukturach armii alianckich $)^{6}$, była Delegatura Rządu na Kraj oraz wyłaniające się struktury

\footnotetext{
${ }^{5}$ Władzę na uchodźstwie pełnili: a) urząd prezydenta - W. Raczkiewicz; b) urząd premiera i naczelnego wodza - gen. W. Sikorski, a od lipca 1943 roku S. Mikołajczyk; c) od lipca 1943 roku naczelnym wodzem był gen. K. Sosnkowski.

${ }^{6}$ Porządkując najważniejsze informacje historyczne z dziejów wojny i okupacji, korzystałem z następujących opracowań: J. Chrobaczyński (2012, 2015), K. Stępnik i M. Rajewski (Komunikowanie
} 
władz cywilnych i wojskowych (przede wszystkim Komitet Walki Cywilnej, Komitet Walki Zbrojnej, Podziemne Siły Zbrojne, oficjalnie podporządkowane Związkowi Walki Zbrojnej/Armii Krajowej).

Od początku okupacji na mapie politycznej wyłaniały się różne stronnictwa, częściowo kontynuujące działalność sprzed wybuchu wojny, a jednocześnie tworzące nowy układ ideologiczny. Na skutek sytuacji wojennej doszło do pęknięć i podziałów politycznych. Podstawą polaryzacji politycznej okazał się stosunek do rządu londyńskiego i jego krajowych reprezentacji (politycznych i wojskowych), a przede wszystkim uznanie (bądź też nie) legalności i zwierzchnictwa władz na uchodźstwie. W skład tak zwanego Polskiego Państwa Podziemnego i Polskich Sił Zbrojnych wchodziły głównie ugrupowania demokratyczne, (post)sanacyjne, narodowe (endeckie), ludowe, lewicy (socjalistycznej i ludowej), które konsolidowały się przez cały niemalże okres okupacji: najpierw tworząc Krajową Reprezentację Polityczną (21 marca 1943 roku), czyli tak zwaną „czwórkę” głównych partii (Stronnictwo Demokratyczne, Stronnictwo Pracy, Stronnictwo Narodowe oraz PPS-WRN), a od 9 stycznia 1944 roku - Radę Jedności Narodowej, pełniącą funkcję parlamentu. Prawie do końca okupacji poza głównym nurtem politycznym i wojskowym pozostawały środowiska polityczne nacjonalistyczne (przed wojną nawiązujące do ideologii faszystowskiej, jak ONR - Obóz Narodowo-Radykalny), a także ugrupowania skrajnej prawicy, współtworzące Narodowe Siły Zbrojne. Do 1944 roku pozostawały one również poza strukturami Polski Podziemnej, gdyż nie uznawały zwierzchności Armii Krajowej i jej komendantów głównych. Wszystkie te ugrupowania - choć na poziomie zróżnicowanej jakościowo (emotywnie) retoryki - w swoich programach ideologicznych traktowały okupację rosyjską na wschodnich terenach Polski (1939-1941) jako agresję ze strony „drugiego wroga”, a stosunek do polityki ZSRR przekładały na obraz wyłaniającego się od 1942 roku ruchu komunistycznego.

Największa linia podziałów politycznych dotyczyła, po pierwsze, polityki polsko-rosyjskiej i postawy wobec Związku Radzieckiego. Po drugie zaś, napięcia i wewnętrzne konflikty polityczne - od 1944 roku przyjmujące postać „wojny wewnętrznej/wojny polsko-polskiej” (Chrobaczyński 2015; por. Kamińska-Szmaj 2014, 2015) - miały swe źródło w ocenie działalności lewicy radykalnej i polskiego ruchu komunistycznego, który umocnił się w Generalnym Gubernatorstwie bezpośrednio po agresji Niemiec na ZSRR (22 czerwca 1941 roku). Ugrupowania, które do tej pory nawiązywały ideowo do tradycji przedwojennej Komunistycznej Partii Pol-

się Polaków... 2011), A. Ignatowicz (2011), W. Bartoszewski (1987), R. Kaczmarek (2010). Na temat języka polityki, głównie w okresie przejmowania władzy przez PPR i początków „władzy ludowej”, więcej w: I. Kamińska-Szmaj (2014, 2016), M. Mazur (2011). Z kolei bardziej szczegółowe informacje na temat podziemnej prasy konspiracyjnej, jej oblicza ideowego, funkcji propagandowych oraz dziejów tekstów propagandowych pochodzą z: J. Jarowiecki (1980 a, b), S. Lewandowska (1992), E. Cytowska (1986). Zob. także wcześniej wymienione opracowania historyczne, prasoznawcze i językoznawcze oraz uwagi z zakresu dziejów polszczyzny wojennej: I. Bajerowa (Język polski czasu... 1996), głównie rozdziały autorstwa K. Kleszczowej, O. Wolińskiej i E. Jędrzejko. 
skiej, zostały włączone w struktury nowej partii. Otóż 5 stycznia 1942 roku w Warszawie odbyło się zebranie założycielskie Polskiej Partii Robotniczej (PPR), w którym uczestniczyła tak zwana grupa inicjatywna, przybyła bezpośrednio z Moskwy i rekrutująca się z członków radzieckiego Kominternu ${ }^{7}$. Przedstawiając deklaracje ideowe, nowa partia wprost wyraziła sprzeciw wobec polityki rządu londyńskiego i struktur państwa podziemnego, a w późniejszym okresie przystąpiła do przejęcia władzy nad wszystkimi ugrupowaniami lewicowymi (ludowymi, chłopskimi, socjalistycznymi), stworzyła też własne siły zbrojne - Armię Ludową.

Polska Partia Robotnicza prowadziła działalność propagandową nie tylko w opozycji wobec władz londyńskich i głównego nurtu polityczno-zbrojnego (ugrupowań „czterech”), lecz także zmierzała do przejęcia władzy nad całym ruchem lewicowym, socjalistycznym i chłopskim. Jej działalności nie akceptowały nie tylko środowiska "antykomunistyczne”, lecz również tradycyjne partie lewicowe, ludowe i syndykalistyczne, jak Stronnictwo Pracy, Polska Partia Socjalistyczna (Wolność-RównośćNiepodległość). Także lewicowe środowiska wojskowe, jak na przykład Gwardia Ludowa czy Bataliony Chłopskie, włączały się w działalność zbrojną u boku Armii Krajowej, tym samym kontestując próby wcielenia ich w struktury Armii Ludowej.

$\mathrm{Na}$ początku 1944 roku - na skutek zerwanych stosunków dyplomatycznych między rządem polskim a władzami ZSRR, a przede wszystkim po przekroczeniu wschodniej granicy Polski przez Armię Czerwoną (3/4 stycznia 1944 roku) - nastąpił proces walki o władzę oraz etap rzeczywistego jej zdobywania. Na przełomie 1943/1944 roku powstała Krajowa Rada Narodowa, uznawana przez ZSRR za jedyną legalną reprezentację władz polskich w okupowanym kraju; z niej wyłoniły się późniejszy PKWN oraz struktury polityczne „Polski lubelskiej” (zob. Kamińska-Szmaj 2014, 2015).

W ostatnim roku okupacji (1944) w polskim dyskursie politycznym retoryka walki z wrogiem układała się w różne ramy („konstelacje”). Przewidywano, że w obliczu ciosów zadawanych Wehrmachtowi przez Armię Czerwoną oraz na skutek aktywności wojsk koalicji antyhitlerowskiej (na przykład po inwazji w Normandii 7 czerwca 1944 roku) wojna się wkrótce zakończy. Dlatego też język walki z niemieckim okupantem stawał się bardziej dyrektywny i apelatywny, a na tle brutalnej rzeczywistości (terroru, masowych zbrodni, Zagłady) wyostrzał się negatywny obraz wroga wojennego. Niemniej z powodu coraz bardziej konfliktowych relacji w podziemnym życiu politycznym, a także aktywnej działalności propagandowej wszystkich ugrupowań, a szczególnie tych, które stały na przeciwległych krańcach „barykady”, rodził się obraz „wroga wewnętrznego”, przeciwnika politycznego, podmiotu antagonistycznych relacji. Deprecjonowano jego obecność i działalność polityczną, walczono z nim o „rząd dusz”. Znakiem podziemnego dyskursu politycznego stała się retoryka walki zarówno z realnym wrogiem wojennym, jak i z wrogiem

${ }^{7}$ Najważniejsze informacje na temat działalności lewicy komunistycznej i radykalnej podaję za: I. Kamińska-Szmaj (2014, 2015), M. Mazur (2011). 
politycznym (propagandowym), a jej stylistycznym symbolem - agresja słowna, poszerzający się w wydawnictwach konspiracyjnych zbiór inwektyw i środków komunikacji negatywnej.

\section{Inwektywa jako narzędzie walki z przeciwnikiem/wrogiem politycznym. Zarys problematyki}

Antagonistyczne relacje między podmiotami komunikacji politycznej (szeroko rozumianego dyskursu politycznego) ujawniają się w każdym typie kultury i praktyki sprawowania władzy - co też przekonująco uzasadnia Katarzyna Kłosińska:

Działanie w obrębie polityki zawsze zasadza się na antagonizmie wynikającym z natury polityczności. W relację antagonistyczną wpisana jest relacja „my”-„oni”, kształtująca tożsamość każdego podmiotu politycznego i z racji swego antagonistycznego charakteru przyjmuje postać „przyjaciel”-„wróg” [...]. Podmiot polityczny może zaistnieć, może uzyskać tożsamość tylko dzięki uwikłaniu w jakąś relację antagonistyczną. (Kłosińska 2016: 113)

Spór polityczny, wynikający z rozbieżności koncepcji ustrojowych, ideologicznych, odmiennego świata wartości i wizji życia społecznego (prawnego), może przyjmować postać racjonalnych zachowań komunikacyjnych opartych na zasadzie dialogu. Zasada ta zwyczajowo wpisuje się w tradycję pluralistycznego systemu politycznego oraz debaty społecznej (Kampka 2014). Przyjmuje się, że taki model konfrontacji w świecie polityki stanowi wzorzec komunikacji racjonalnej (koncepcja filozoficzna Jürgena Habermasa, por. Warchala 2016; Dobek-Ostrowska 2004; Kampka 2014 i inne), a relewantna wobec niej kategoria „przeciwnik/wróg” jest figurą retoryczną, składnikiem aktów perswazji politycznej (por. Fras 2006; Ożóg $2004)^{8}$. Jest to zatem naturalny stan komunikacji politycznej, wpisany w logikę walki o władzę oraz metody sprawowania rządów, o czym również pisze Sabina Olszyk:

W retoryce politycznej przeciwnikiem jest podmiot, z którym się polemizuje, przeciw któremu kieruje się swą wypowiedź, traktując go jednak tylko i wyłącznie jako konkurenta dążącego do tego samego celu co „my”. (Olszyk 2013: 17)

Niemniej w sytuacjach kryzysu społecznego, czytelnych podziałów politycznych, ideowych, w sytuacji ostrych polaryzacji społecznych (por. Reykowski 2002), retoryka antagonistyczna przenosi się do przestrzeni komunikacji negatywnej (Sarnowski 1999), a rywalizacji politycznej może towarzyszyć język walki (Reykowski 1984), w skrajnych przypadkach — retoryka nienawiści (Głowiński 2007) i język wrogości (Czyżewski 2007). Wówczas perswazyjnym wykładnikiem konfliktowych

${ }^{8}$ Jak pisze K. Ożóg (2004: 61-62), dwubiegunowe wartościowanie świata politycznego, czyli umieszczanie znaczeń na skali aksjologicznej „dobry-zły”, sprowadza się w języku perswazji politycznej do konceptualizacji przeciwnika, przy czym intencja negatywnego wartościowania może przyjmować postać działań komunikacyjnych służących konceptualizacji „politycznego wroga, którego należy zniszczyć” lub „kategorii przeciwnika, z którym należy się porozumieć”. 
relacji między uczestnikami dyskursu publicznego stają się środki dyskredytowania i pejoratywnego wartościowania przeciwnika, naruszające jego godność, służące szkalowaniu lub publicznemu piętnowaniu jego działań, najogólniej — sytuujące się w obrębie negatywnych (agresywnych) zachowań mownych (jak na przykład obelga, drwina, kpina, szyderstwo) i równie pogardliwych (obraźliwych) aktów/gatunków mowy, które tworzą pole komunikacyjne inwektywy politycznej (zob. przede wszystkim Kamińska-Szmaj 2007; Zimny, Nowak 2009). Ich dobór zależny jest od całego kontekstu pozajęzykowego i warunków pragmatycznych, na które wpływ mają między innymi: 1) sytuacja komunikacyjna (w tym układ nadawczo-odbiorczy oraz rola w nim adresata obelgi/wypowiedzi lżącej); 2) kreowany obraz świata politycznego (czyli ideologia i wartości wpisane w semantykę tekstów politycznych); 3) typ panującej kultury politycznej (hegemoniczny/monologowy lub pluralistyczny/dialogowy); 4) system medialny i model propagandy (totalitarny lub demokratyczny) (por. Kamińska-Szmaj 2013; Fras 2006; Garlicki, Noga-Bogomilski 2004 i inne).

Sposób negatywnego wartościowania przeciwnika może mieć charakter wariantywny, skalarny, motywowany zamiarami politycznymi lub formą zachowań propagandowych, przy czym w sytuacji komunikacji negatywnej, sięgającej po narzędzia agresji słownej, zwykle figura „rywala/przeciwnika” przyjmuje postać „wroga” (por. Olszyk 2013; Ożóg 2004) $)^{9}$. W literaturze przedmiotu opisującej zjawisko przemocy komunikacyjnej (lub mowy nienawiści) można odczytać ponadto konstatację, że środki deprecjacji wroga (adresata napaści słownej) mają charakter lżący i służą całkowitemu usunięciu, wykluczeniu go z życia politycznego (społecznego), ze wspólnoty komunikacyjnej ${ }^{10}$.

W badaniach na temat agresji w języku polityki środki konceptualizacji przeciwnika za pomocą figury „wroga” zwykle opisuje się w kategoriach „etykietowania”

9 S. Olszyk, przyglądając się skrajnie nacechowanym, pejoratywnym konceptualizacjom „przeciwnika politycznego" we współczesnym dyskursie politycznym i odwołując się do różnych teorii „wrogości” w badaniach filozoficznych, socjologicznych i politologicznych, wprowadza pojęcie „stereotypu WROGA”, które eksplikuje w sposób następujący: „Stereotyp wroga, będący szczególnym rodzajem stereotypu politycznego [...] powstaje i kształtuje się na gruncie stereotypu „obcego” i zawsze jest stereotypem negatywnym, eksponującym cechy ujemne. Stanowi schematyczny, silnie zabarwiony emocjonalnie, negatywny obraz jednostki, grupy, instytucji, państwa itp., postrzeganych jako zagrożenie dla istnienia lub realizacji celów innych podmiotów”. Jak dodaje badaczka, „stereotyp wroga jest najczęściej zjawiskiem stworzonym (stanowi rezultat perswazji i manipulacji), zmierzającym do ukazania wroga w jak najgorszym świetle, celem wyeliminowania go z gry" (Olszyk 2013: 21).

10 Zjawisko „mowy nienawiści” ma charakter publiczny, dotyczy stereotypizacji i skrajnego, ideologicznego myślenia, powstałego niekiedy na poziomie działań propagandowych („wróg polityczny” - ujmowany pod figurą „wroga obiektywnego" lub „kozła ofiarnego” - to immanentna cecha komunikacji propagandowej o charakterze totalitarnym). Współcześnie sytuuje się je w polu zjawisk związanych z dyskryminacją, dehumanizacją, degradacją i wykluczeniem drugiego człowieka, a więc aktów napaści werbalnej sięgających po stereotypy, klisze rasistowskie, uprzedzenia o charakterze etnicznym, religijnym itp. W literaturze przedmiotu na ten temat między innymi w: S. Kowalski, M. Tulli (2003), A. Cała (2012), A. Cegieła (2014), J. Linde-Usiekniewicz (2015); por. także M. Głowiński (2002, 2007), B. Witosz (2010) oraz M. Reisigl (2010). 
(labbelingu) (Kochan 1994; por. Nowak 2002; Zimny, Nowak 2009; Taras 2013), „stygmatyzacji językowej” (Cegieła 2014), a szerzej — „inwektywy politycznej”. Pomijając szczegółową charakterystykę zjawisk mieszczących się w obrębie werbalnych środków obrażania przeciwnika, sięgam po definicję opisywanego zjawiska zaproponowaną przez Irenę Kamińską-Szmaj. Według wrocławskiej badaczki w polu inwektywy politycznej mieszczą się

celowe zachowania słowne, mające charakter publiczny i dotyczące uczestników życia politycznego, wyrażające negatywne emocje nadawcy względem osoby, grupy osób bądź instytucji, ideologii i/lub wartościujące kogoś (coś) negatywnymi środkami językowymi funkcjonującymi w świadomości określonej wspólnoty komunikacyjnej jako obraźliwe [...] lub środkami językowymi nienacechowanymi aksjologicznie i/lub emocjonalnie, które dopiero przez kontekst słowny i komunikacyjny (polityczny, społeczno-historyczny) otrzymują nacechowanie negatywne. (Kamińska-Szmaj 2007: 58)

\section{Retoryka walki z wrogiem/przeciwnikiem politycznym. Najważniejsze toposy}

Antagonistyczne relacje $\mathrm{w}$ polskim dyskursie politycznym opisywanego okresu sprowadzały się do walki z wrogiem, lecz kategoryzacja tego wroga była wariantywna lub skalarna. Po pierwsze, nie wszystkie podmioty polityczne jednakowo definiowały okupanta/wroga wojennego. O ile postawa działaczy podziemnych ugrupowań politycznych i wojskowych wobec agresji i okupacji hitlerowskiej była jednolita, o tyle ocena polityki ZSRR, a przede wszystkim okupacji rosyjskiej (19391941) oraz polityki Stalina w sprawie polskiej (od 1943 roku), była zróżnicowana, nierzadko stawała się źródłem konfliktów wewnętrznych. Różnice te odzwierciedlały peryfrazy pojawiające się w prasie podziemnej, jak na przykład wróg numer 1 (Niemcy), nasi wrogowie numer 1 i numer 2 (Niemcy i Rosja), neutralna wrogość ('negatywny stosunek do polityki ZSRR, ale umiarkowany program walki politycznej/zbrojnej). Po drugie - odmienne koncepcje walki zbrojnej (na przykład między Armią Krajową a Armią Ludową) oraz nieustabilizowana polska polityka zagraniczna powodowały, że rywala politycznego nazywano albo przeciwnikiem politycznym, albo wrogiem (wewnętrznym). Językowy obraz wroga, sposób profilowania opozycji MY-ONI, a przede wszystkim kontekst polityczno-ideologiczny wpływały na dobór środków wykorzystywanych w relacjach antagonistycznych. Zwykle sprowadzał się on do retoryki ostrych kategoryzacji i form agresji werbalnej. Źródłem zaś podziałów ideologicznych, a tym samym wielogłosowej publicystyki konspiracyjnej, były następujące tematy: aspekty dychotomicznych ocen, odzwierciedlane często w charakterystycznych słowach kluczach poszczególnych wspólnot politycznych: 
— stosunek wobec rządu na emigracji (uznanie jego legalności lub delegitymizacja), w tym ocena postawy przywódców polskich we wrześniu 1939 roku, na przykład rzad na wychodźstwie//emigracyjnal/sanacyjna klika;

- działalność lewicy komunistycznej, ocenianej często z punktu widzenia polityki ZSRR, na przykład piąta kolumnal/braterstwo walki;

- stosunek do polityki polsko-rosyjskiej, a od 1943 roku w sprawie opublikowanych przez propagandę niemiecką informacji na temat zbrodni w Katyniu (na przykład tak, to prawda; mord w Katyniu; zbrodnia smoleńskal/katyńska prowokacja Hitlera; najpotworniejsza zbrodnia hitlerowska; reakcja polskal/jedyny rząd, który dat się wciagnać w machinacje hitlerowskie itp.);

- działalność konspiracyjna - własna i przeciwnika, na przykład bohaterski// $z d r a d z i e c k i, \mathrm{w}$ tym postawa wobec programów walki zbrojnej, na przykład jednolity front//walki bratobójcze; jedność//zdrada;

- ocena przedwojennych i przyszłych programów ustrojowych dotyczących praw mniejszości etnicznych, narodowych, na przykład demokratyczny//faszystowski.

Nośnikami wielu inwektyw stawały się konotacje na temat Związku Radzieckiego - posługiwano się nimi, aby podważyć działalność ruchu komunistycznego (PPR-u). Warto w tym miejscu podkreślić, że na skutek doświadczeń wojennych dopiero w okupacyjnym dyskursie prasowym powstawał obraz totalitarnej, imperialistycznej polityki wschodniego sąsiada względem Polski (por. Jaeschke 2002). Pojawiał się on zarówno w gazetach reprezentujących politykę rządu londyńskiego, jak i w publicystyce całego nurtu lewicy socjalistycznej (PPS-WRN), występującej programowo (ideologicznie) przeciwko sanacyjnemu odłamowi rządu, ale równie donośnie przeciwko odłamowi lewicy komunistycznej. O ile propagandowy wizerunek ZSRR miał charakter gloryfikujący w całej działalności publicystów związanych z PPR-em i lewicą radykalną, o tyle warto przypomnieć, że przez cały okres okupacji pojawiał się negatywny (a niekiedy emotywnie nacechowany) obraz wschodniego sąsiada w piśmiennictwie lewicowym i ludowym. Przykładowo gazety lewicowe, a przede wszystkim wywodzący się z okresu przedwojennego „Robotnik”, podejmując problematykę polsko-rosyjskich relacji politycznych, posługiwały się nacechowanymi pejoratywnie określeniami na temat ZSRR, przenosząc je często na obraz wroga wewnętrznego, czyli PPR-u, na przykład: być pod butem Stalina, być kandydatem na sowieckiego wasala, paść na kolana przed Moskwa, imperialistyczne apetyty sowieckie, oddać się pod protektorat Rosji itp. Aby wzmocnić negatywny wizerunek wschodniego sąsiada, często sięgano po analogie między hitleryzmem a stalinizmem, co przekładało się na implikowane sądy na temat koncepcji ustrojowych/politycznych lewicy komunistycznej czy rzeczywistej polityki przejmowania przez nią władzy w 1944 roku (przede wszystkim kosztem ugrupowań lewicowych), na przykład: rosyjsko-niemiecka spółka („Robotnik w Walce” WRN 7 listopada 1943 roku); zbrodnicza sielanka wspótpracy Gestapo i NKWD („Robotnik w Walce” 17 września 1943 roku); walka $z$ niemiecka zaborczościa $i$ wschodnim barbarzyństwem („Robotnik” WRN 23 stycznia 1944 roku); haniebny akt wspólnictwa między 
Rosją sowiecka a hitlerowskimi Niemcami („Robotnik” WRN 23 stycznia 1944 roku); państwa zgwałcone przez Sowiety w czasie sojuszu z Hitlerem („Robotnik” 7 listopada 1943 roku); sobowtóry, Johan i Iwan [...] stali w jednym domu, który był [...] cudzym domem („Robotnik” WRN 23 stycznia 1944 roku).

Punktów spornych w całej narracji okupacyjnej było więcej — nie sposób wyeksponować wszystkich kategorii ideologicznych, politycznych, społecznych, a przede wszystkim koncepcji walki zbrojnej, które rzutowały na donośny język polemiki politycznej i kształtowały negatywny obraz przeciwnika/rywala politycznego nazywanego „wrogiem”. W badanych tekstach typowa dla języka polityki dychotomia aksjologiczna MY-ONI jest wyrazista, ale jednocześnie heterogeniczna na poziomie doboru konotacji znaczeniowych. Autorzy konspiracyjnych tekstów publicystycznych posługują się różnymi środkami deprecjacji - w tekstach bardzo często zlewają się nośniki aktualnych znaczeń z odniesieniami do języka polityki okresu międzywojennego. Negatywizm świata, a przede wszystkim sytuacji wojennej, służy umacnianiu wizji związanych z wyobrażeniami na temat przyszłego, odrodzonego państwa. Dlatego też niezwykle agresywna polemika z wrogiem staje się dla nadawców punktem wyjścia do ekspozycji własnych deklaracji ideowych jako lepszych lub pożądanych.

Atmosferę tej polemiki, a przede wszystkim zakres stylistyczny środków używanych do deprecjacji przeciwnika, ilustruje kilka wyrazistych przykładów, w których ujawniają się cechy perswazji politycznej opisywanego okresu, a jednocześnie jej donośny ton. Po pierwsze, wiele strategii zachowań językowych opierało się na rekontekstualizacji dawnych toposów propagandowych, czyli polegało na naśladowaniu typowych dla języka polityki dwudziestolecia metafor, inwektyw, epitetów w nowych użyciach (jak na przykład często stosowane metonimie zwierzęce i animizacje; por. Kamińska-Szmaj 1994). W strategiach tych wybijają się postawy rozliczeniowe związane z polityką przedwrześniową - jak we fragmentach artykułów zamieszczonych w gazetach lewicowych („Robotnik”, „Walka WRN”), w których często przewija się krytyczny (negatywny) stosunek do odłamu sanacyjnego w rządzie emigracyjnym, utożsamianego z rządami przedwojennymi, na przykład:

Niesłychaną żywotność wykazuje pognębiona, zdawałoby się już raz na zawsze, hydra sanacyjna. Gdy w haniebnym dla sanacji roku 1939 mierny aktorzyna, krygujący się na wodza Rydz-Śmigły, zeszedł ze sceny, gdy cała ta „elita od łamania kości” wykazała kompletną zgniliznę i niemoc w obliczu wroga niszczącego ogniem i żelazem nasze ziemie, wydawało się, że zgangrenowane cielsko sanacyjnego wilkołaka zgnije do reszty. Ale gdzie tam! Sanacja przyczaiła się tylko, wylizując się ze swych ran. Sanacja nie wyzbyła się jednego pragnienia, które ją rozpiera, ożywia i regeneruje: żądzy władzy, żądzy „trzymania za mordę” za wszelką cenę. (Rob 26 lipca 1943 roku)

Tak tam [na emigracji - M.P.], jak i w Kraju, zwarły się ze sobą w cichym sojuszu elementy endeckie z sanacyjnym bankrutem i w wielkiej zgodzie przygotowują się do ponownego ujęcia władzy w swe ręce. (Walka WRN 25 czerwca 1943 roku)

Po drugie, wątkom rozliczeniowym często towarzyszyła retoryka mobilizacyjna: poprzez negację świata ONYCH (najczęściej ustroju Polski przedwojennej, 
określanej często za pomocą synekdoch motywowanych od nazwisk przywódców: Beckowie, Sosnkowscy, Rydzowie) legitymizowano działania propagandowe odnoszące się do przyszłości, a przede wszystkim wyrażające wspólnotę świata i języka. Był to bardzo charakterystyczny topos w języku propagandy politycznej PPR-u, ewokujący całą narrację na temat walki o władzę za pomocą „rewolucyjnej” opozycji „przeszłość-przyszłość”: postęp-wstecznictwo/reakcja, Polska ozonowo-sanacyjna/Polska wyzwolona itp. Przykładem niech będzie fragment „rozliczeniowego” artykułu autorstwa Wandy Wasilewskiej, który został opublikowany w tygodniku „Wolna Polska”, wydawanym pod patronatem Związku Patriotów Polskich:

Nie mogą do decydujących wpływów w wyzwolonej Polsce wrócić ci, którzy trzymali naród „za mordę”, którzy kumali się z Hitlerem, knuli przeciwko Związkowi Radzieckiemu i doprowadzili kraj do zguby [...]. Wara od Polski tym, którzy ją zgubili — Beckom, Sosnkowskiemu i S-ce. (WP 24 stycznia 1944 roku)

Po trzecie, język walki z przeciwnikiem wyrażał agresywne postawy w sposób konkretny, co znaczy, że walka nie miała charakteru wyłącznie retorycznego, ale również orzekano o niej (traktowano ją) w sposób dosłowny. Tę pragmatykę odzwierciedlały często stosowane predykaty z pola semantycznego przemocy czy działań militarnych (rozbić, unicestwić, rozprawić się, zniszczyć, pokonać, oczyścić teren), używane jako wykładniki treści dyrektywnych skierowanych do czytelnika. Przykładem niech będą fragmenty wynotowane $\mathrm{z}$ odmiennych ideologicznie tygodników - wydawanych pod patronatem PPS-WRN („Gwardia Ludowa WRN”) i endecji („Naród”):

[...] unicestwić wszelkie oddziaływania anarchizujące, na szczęście malejących grup, nazywających się narodowymi, oenerowymi, sanacyjnymi czy też ozonowymi [...] rozprawić się z działalnością agentur sowieckich i komunistycznych spod znaku tak zwanego Związku Patriotów Polskich, PPR-u, różnych oszustów podszywających się pod naszą nazwę „Gwardia Ludowa”. (GwLud WRN wrzesień 1943 roku)

Przede wszystkim należy wobec tego steku inwektyw oczyścić teren, a później rąbnąć słowa prawdy tak dosadnie, żeby sanacja raz wreszcie zrozumiała przyczyny swego znienawidzenia przez całe [...] społeczeństwo. („Naród” październik 1943 roku)

Mimo że w prasie konspiracyjnej znajdujemy wiele przykładów wypowiedzi agresywnych, szczególnie w tekstach programowo „zaangażowanych” w walkę z przeciwnikiem politycznym, w wielu artykułach pojawia się również postawa refleksyjna, wyrażająca krytyczny stosunek publicystów wobec napiętej sytuacji w okupowanym kraju. W materiale można wskazać wiele wypowiedzi odzwierciedlających postawę obserwatora, który wyraża niepokój o losy kraju, krytycznie patrzy na spory, podziały i brak jedności. Przykładowo socjalistyczny „Kurier” w taki oto ironiczny sposób charakteryzuje rozbicie polityczne Polski podziemnej:

I jakie to niedobrane towarzystwo ma w życie wprowadzić wolność, równość, braterstwo, kiedy jeden na drugiego patrzy wilkiem? [...] Jakaż to będzie równość obszarnika $z$ endecji z chłopem ze Stronnictwa Ludowego, a „socjalisty z WRN” z dygnitarzem sanacyjnym z A.K.? Jakież 
będzie braterstwo paskarza oenerowskiego z chłopem z „Batalionu Chłopskiego”? To są tragiczne kpiny. (art. Przyszła Polska w piśmie socjalistów „Kurier” 27 maja 1944 roku)

Sytuację tę obrazowała również leksyka (frazeologia) odnosząca się do takich negatywnych zjawisk/antywartości, jak: 1) 'brak jedności/rozbicie’: rozkładowe działania, kandydaci na wodzów, byle zasiadać na siodle, rozkładowe działania, sprzedawczykostwo i nieprawości wszelakie; 2) 'anarchia': rokosz (sanatorów), partyjniactwo, doktrynerzy, karierowicze, knowania spiskowe, polityczne warcholstwo; 3) 'spory/ konflikty polityczne': krwawa rozprawa; przeprowadzać zamach stanu $w$ „aureoli praw", brudna robota, awanturnik polityczny, dywersja polityczna; 4) 'walka o przywództwo': marzyć o dyktaturze, po trupach do władzy, partyjniactwo, karierowicze ze wszystkich możliwych obozów politycznych; 5) 'czyny, działania, postawy zagrażające konspiracji, szczególnie zbrojnej’: zabawa w konspirację, działalność wysoce szkodliwa dla narodu polskiego, gorszace i szkodliwe wyczyny itp.

Zjawiska uznawane za negatywne często eksponowano, zestawiając je ze słownictwem konotującym obrazy, cechy uznawane za pozytywne (pożądane czy deklarowane). W celu wzmocnienia aksjologii porównawczej lub dychotomicznej stosowano antytezy: 1) na poziomie doboru wyrazów o przeciwstawnych znaczeniach w jednej syntagmie, na przykład: anarchia-jedność; samodzielne działania zbrojne-jedność Polski; rozkład wewnątrz Narodu-zwarty front całego Narodu; widmo anarchii-zgoda narodowa; zło a zdrowy rdzeń narodu; antyhitlerowski front-zhitleryzowanie świata; szeroki front polskiego wstecznictwa-gotowe na wszystko szeregi walczacego ludu lub 2) na poziomie bardziej rozbudowanych wypowiedzeń, haseł, zawiadomień wpisanych w strukturę tytułu - na przykład: Kompromis londyński i sanacyjne knowania spiskowe („Robotnik” 24 maja 1942 roku); Prosta droga i błędne ścieżki („Robotnik” 14 grudnia 1942 roku); Motory i hamulce („Głos Warszawy” 6 czerwca 1944 roku); Demokracja i faszyzm („Głos Warszawy” 13 czerwca 1944 roku); W parze ze szkalowaniem naszego życia politycznego idzie sławienie własnych agentur (BI 6 lipca 1944 roku); Kłamstwem jest, jakoby londynssy emigranci kierowali walka narodu polskiego. Prawda natomiast jest, że walkę tę sabotowali („Głos Warszawy” 21 stycznia 1944 roku); Każdy agent gestapo, pomagający mordować własnych braci, może równocześnie być dobrym patriotą („Głos Warszawy” 21 stycznia $1944 \mathrm{roku})$.

Przywołane przykłady pokazują, że antyteza - jako środek pozwalający wzmacniać wartościowanie zjawisk sytuujących się na przeciwległych biegunach aksjologicznego continuum - to nie tylko jeden $\mathrm{z}$ najbardziej popularnych werbalnych środków perswazji w sensie ogólnym, lecz także dość rozpoznawalny i bardzo często wykorzystywany chwyt retoryczny w tekstach propagandowych opisywanego okresu.

Środki dyskredytacji nabierają cech inwektywy politycznej, jeśli ujawniają się w nich konotacje o treściach ideologicznych, pokazujące związek negatywnie postrzeganych zjawisk z konkretnym adresatem aktu wartościowania. Pragmatyka 
wypowiedzi sytuuje się zaś w polu agresji werbalnej, jeśli przeciwnik — adresat napaści słownej - nominowany jest jako wróg. Leksem wróg w języku propagandy politycznej okresu wojennego na poziomie denotacyjnym odnosi się do okupanta, na poziomie konotacyjnym staje się jednym z najłagodniejszych określeń przeciwnika politycznego (por. Wolińska 1996: 351). Jest to wyraz szczególnie pojemny semantycznie, a jednocześnie nośny perswazyjnie, gdyż w swej rozmytej referencji ujmuje świat „antywartości”, z którymi nie identyfikuje się nadawca wypowiedzi propagandowej. Jest to również leksem wyrazisty pragmatycznie, gdyż otwiera pole różnych działań illokucyjnych, jak: negatywne wartościowanie, poniżanie, szkalowanie, ośmieszanie, niszczenie za pomocą słowa, wykluczenie itp., a więc zamiarów związanych z walką z przeciwnikiem, pokonaniem go za pomocą słowa.

Leksem wróg jako nominacja przeciwnika politycznego w prasie konspiracyjnej nie pojawia się na powierzchni tekstu zbyt często, a jeśli już — to w dość utartych kolokacjach typu:

\section{[1] [rzeczownik + przymiotnik]}

- o charakterze relacyjnym (klasyfikującym), na przykład wróg wewnętrzny - czyli 'nieprzyjaciel', 'przeciwnik', 'obiekt napaści i antagonistycznych relacji' w odróżnieniu od wroga zewnętrznego, czyli 'okupanta': „Sprawie odbudowy rzucać będzie kłodę pod nogi wróg zewnętrzny i wróg wewnętrzny” („Barykada Wolności” 15 kwietnia $1941 \mathrm{roku}$ );

- o charakterze jakościowym, na przykład wróg śmiertelny - czyli 'nieprzyjaciel, z którym należy walczyć - symbolicznie lub zbrojnie - albo potępiane zjawiska z nim skojarzone’: „Na naszej drodze stoi drugi wróg śmiertelny. Bolszewickie oddziały dywersyjne z Gwardią Ludową, jej przybudówkami i ośrodkiem dyspozycyjnym w Moskwie” („Szaniec” 4 grudnia 1943 roku);

\section{[2] [syntagmy orzecznikowe]}

- o charakterze orzekającym, czyli przypisujące zjawiskom nieakceptowanym cechy skrajnie negatywne, wzbudzające postawę wrogości: „Oto w tej wojnie znalazł się nowy wróg, który usiłuje od wewnątrz osłabić jednolitość naszego Narodu. Wrogiem tym jest komunizm" (RzP 6 sierpnia 1944 roku);

\section{[3] [rzeczownik + rzeczownik]}

- o charakterze relacyjnym, przypisujące adresatowi aktu wartościowania (skrajnie) negatywne postawy wobec zjawiska uznawanego przez nadawcę za pozytywne, na przykład wróg + odbudowy/ludu/zmian/proletariatu.

Częściej niż rzeczownik używany jest przymiotnik wrogi. Pojawia się on w różnych kontekstach: 1) wskazujących 'obcość zjawiska, niechętną postawę wobec desygnatów, których wartość się w tekstach pomniejsza (na przykład wroga propaganda, wroga działalność + 'czyjass', także szeregi typu: wroga i wywrotowa działalność, wroga i reakcyjna propaganda) lub 2) w kontekstach przypisujących przeciwstawne (negatywne) postawy wobec zjawiska, o którym orzeka się pozytywnie, na przykład wrogi + demokracji, reformom, narodowi, społeczeństwu, olbrzymiej części narodu (w tym użyciu jest to synonim przymiotnika obcy w znaczeniu wykluczającym). 
Kategoria wroga politycznego dotyczyła nie tylko przypisywanych mu negatywnych konotacji odnoszących się do świata z nim utożsamianego, czyli programów, wizji ustrojowych, działaczy politycznych, ideologii i sojuszy, lecz także przyjmowała postać retoryki wykluczającej. Jednym z najbardziej nacechowanych toposów służących pomniejszaniu przeciwnika jest zarzut bratobójstwa, zdrady lub współpracy $\mathbf{z}$ okupantem. Asocjacje tego typu mają zdegradować przeciwnika, a przede wszystkim służą przenoszeniu realnego obrazu wroga wojennego/zewnętrznego (okupanta) na perswazyjny, propagandowy obraz adresata polemiki politycznej. W tym wypadku mechanizm konotacji, aluzji opiera się na treści presuponowanej: ' $X$ postępuje jak $Y=$ wróg, a więc działa na jego korzyść/kolaboruje $z$ wrogiem $=$ Y-em'. Wśród etykietek tego typu pojawiają się głównie rzeczowniki prymarnie lub sekundarnie wskazujące na to, że nosiciel inwektywy to zbrodniarz, bandyta, morderca (polityczny) albo szaleniec, szkodnik, natomiast zjawiska uznawane za niebezpieczne/godne potępienia przedstawia się za pomocą rzeczowników lub wyrażeń typu: bandytyzm, bratobójstwo, walka bratobójcza, zbrodnia bratobójcza, zbrodnia kainowa, wojna domowa, krwawe porachunki, bandytyzm polityczny, mordy na przeciwnikach, haniebne mordy itp.

Słownictwo z pola leksykalnego zbrodni, zachowań kryminalnych obrazuje tematykę artykułów, które pojawiły się w prasie konspiracyjnej na przełomie 1943/1944 roku, gdy rzeczywiście doszło do wyrazistych podziałów nie tylko na scenie politycznej, lecz także w obrębie konspiracyjnych ugrupowań zbrojnych. Przede wszystkim w dyskursie - bez względu na przynależność ideologiczną redakcji prasowych - sięgano po środki wartościowania przeciwników, które opisywały ich działalność jako wojnę domowa. Za skrajnie negatywne zjawiska uznawano walki zbrojne między reprezentantami konspiracyjnych oddziałów wojskowych, a także brak woli porozumienia, podporządkowania się dowództwu sił zbrojnych (działać przeciwko jedności, nieprzemyślane kroki wojskowe), por.: rodzimi zbrodniarze, bandytyzm [PPR o AK]: „Jeśli nie sparaliżujemy zawczasu wysiłków rodzimych zbrodniarzy, mogą oni oddać okupantowi olbrzymie usługi [...] potrafią ci zdrajcy dotrzeć i zadać cios w plecy nawet tam, gdzie okupant dotrzeć nie może" (Tr Wol 22 marca 1944 roku), „Bandytyzm zakwitł najbardziej [...] w szeregach AK, zdemoralizowanych bezczynem i wyczekiwaniem końca wojny" (Tr Wol 2 marca 1944 roku); bandytyzm polityczny [PPS-WRN o NSZ]: „praktykowane akty bandytyzmu politycznego i dokonywane mordy na przeciwnikach politycznych, demaskują właściwe nastawienie moralne tak zwanej armii narodowej" (GW Lud WRN 1 października 1943 roku); szaleńcy, szeregi szkodników [AK o NSZ]: „Każdy, kto działa przeciwko jedności wojska jest szaleńcem" [AK o NSZ] (BI 25 listopada 1943 roku); [AK o NSZ]: „Komenda "Narodowych Sił Zbrojnych" wykazała brak instynktu państwowego. Samowolne, nieprzemyślane kroki wojskowe i polityczne tej organizacji kosztują Polskę zbyt wiele, aby mogły być tolerowane. Wszystko co zdrowe - musi szybko i zdecydowanie opuścić szeregi szkodników" (komentarz do rozkazu Tadeusza „Bora”-Komorowskiego, BI 25 listopada 1943 roku). 
Przeciwnikom zarzuca się, że ich pisma mobilizują czytelników do aktów agresji, czyli szerzą hasła + zbrodniczego rozpasania, wojny domowej, walk bratobójczych, albo w podobny sposób przedstawia się działania lub zamiary środowisk związanych ze stroną przeciwną (organizują mordy, sq̨ odpowiedzialni za falę mordów, rozpętują walki bratobójcze, zadaja cios). Dość często używa się słownictwa powiązanego w szeregi składniowe, aby tym samym poszerzyć konotacje i wzmocnić składnik emocjonalny oceny, na przykład okrucieństwo i bestialstwo, haniebny i potworny obyczaj, wojna domowa i masowa denuncjacja, sianie nienawiści i szczucie wojenne. Wyrażenie walka bratobójcza (często w formie pluralnej, wzmacniającej obraz zjawiska potępianego) pojawia się w publicystyce opozycyjnych wobec siebie nurtów polityczno-wojskowych, na przykład: (w prasie pepeerowskiej) „AK odpowiedzialna jest za falę mordów politycznych i rozpętywanie walk bratobójczych" (Tr Wol 22 marca 1944 roku); „Hasło walk bratobójczych obce jest i wrogie olbrzymiej części narodu i dlatego naród ze wstrętem i nienawiścią odwraca się od inspiratorów i wykonawców haniebnych mordów" (Tr Wol 22 marca 1944 roku); (w prasie akowskiej) „bratobójcze walki, stoczone między oddziałami przynależnymi do różnych obozów politycznych" (BI 29 czerwca 1944 roku).

Za charakterystyczne zjawisko podziemnego dyskursu politycznego należy uznać użycie etykietek, które - jak wcześniej wspomniałem - konotują negatywny obraz przeciwnika politycznego na poziomie asocjacji z okupantem. Zapisane są w nich bowiem obrazy negatywnych wydarzeń, doświadczeń wojennych, które mają za zadanie jednoznacznie zakwalifikować świat przeciwnika $\mathrm{w}$ centrum zjawisk zasługujących na potępienie, gdyż zderza się on - w opinii nadawcy z prawem konspiracyjnym (rzeczywistym oraz zwyczajowym). Do najważniejszych, a jednocześnie „najmocniejszych” słów obraźliwych - w kontekście polemiki politycznej i świadomości społecznej - należą epitety, wyrażenia, peryfrazy oparte na supozycji, że adresat inwektywy naśladuje metody postępowania okupanta albo z nim kolaboruje. Takie skojarzenia mają wzbudzać szczególną odrazę na temat „wroga politycznego", a być może wywoływać strach wśród czytelników. Redaktorzy prasy konspiracyjnej chętnie w funkcji epitetu wykorzystują więc leksykę odnoszącą się do pola semantycznego związanego ze światem totalitaryzmu (czarna, brunatna, czerwona + dyktatura, faszyzm, hitleryzm, komunizm, Komintern, Bolszewia, Hitleria). O ile leksyka ta w okresie przedwojennym sytuowała się w różnych kontekstach aksjologicznych (chodzi głównie o nazewnictwo związane z polem wyrazowym 'faszyzm', 'komunizm' - por. Karamańska 2007, Kamińska-Szmaj 1994), o tyle w czasie wojny wskazane określenia — szczególnie odnoszące się do totalitaryzmu hitlerowskiego - nabierają wyrazistości semantycznej, czyli są znakiem zjawisk wyłącznie pejoratywnych, tak w propagandzie, jak i w świadomości odbiorczej, na przykład: faszysta polski: „widownia zbrodni dokonanej przez polskich faszystów" (Rob WRN 17 września 1943 roku); mentalność faszystowskal wpływy totalizmu faszystowskiego: „mentalność przesiąknięta wpływami totalizmu faszystowskiego” (Gw Lud WRN wrzesień 1943 roku); faszystowskie knowania: „Nie 
przypisujemy większego znaczenia ani sanacyjnym intrygom, ani komunistycznym czy faszystowskim knowaniom [...] przeciwko demokratycznej Polsce" (PPS WRN 17 września 1943 roku).

Co więcej, leksemy faszysta, faszystowski czy komunista, komunistyczny jako podstawa etykietek mają wywołać również skojarzenia z rzeczywistością przedwojenną, gdyż nawiązują do symboli dyskursywnych tego okresu. Niemniej najbardziej wyraziste konteksty tworzą inwektywy oparte na słownictwie zaczerpniętym z pola leksykalno-semantycznego opisującego Trzecią Rzeszę (por. przykłady z grupy 1.) i ZSRR (por. przykłady z grupy 2.) jako wroga, a przede wszystkim modelowe reżimy totalitarne. Wówczas treść inwektywy staje się dosadna, ponieważ ma wzmacniać supozycję, że adresat aktu obrażania postępuje podobnie jak wróg, stosuje jego metody, jest zatem groźny, na przykład:

- moralność germańska (ironicznie: 'postępowanie charakterystyczne dla Niemców-okupantów, a więc niehumanitarne, niemoralne itp.'): „Wojna obecna prowadzona jest przez Niemców sposobami zwierzęcymi, wśród podłości i w podeptaniu praw. Nic więc dziwnego, że społeczeństwo polskie z najwyższym niepokojem śledzi, czy zatrute opary "moralności germańskiej« nie opanują także dusz polskich. Gdzieniegdzie, niestety, zdarzają się takie wypadki” (BI 6 lipca 1944 roku);

- orientacja proniemiecka wśród waskiej kliki reakcji polskiej: „O istnieniu takiej orientacji proniemieckiej wśród wąskiej kliki reakcji polskiej, podyktowanej nie interesem polskim, a wspólną nienawiścią do robotniczego państwa Sowietów, choćby ze zdradą własnej Ojczyzny - wiemy od dawna, ale wara tej nędznej klice od prawa występowania w imieniu Narodu Polskiego" (Rob 7 marca 1944 roku);

- polscy esesowcy - niemieckie pachołki: „Reakcja musiała zorganizować kadry polskich, podległych faszystowskiej klice Sosnkowskiego, SS-owców [o AK]. Dziś rozkazy kliki faszystowskiej wykonują polscy esesowcy - niemieckie pachołki, kainowe drużyny Sosnkowskiego" (WP 1944, nr 14-15);

- metody sowieckie: „Hasła swe i metody pracy PPR zmienia odpowiednio do haseł i metod pracy i rządu sowieckiego. Czy to się tyczy polityki międzynarodowej, czy też spraw polskich (Katyń, los Polaków w Rosji, o których nigdy się nie wspomina, stosunek do ś.p. gen. Sikorskiego, do rządu i wodza naczelnego, do spraw granic itd.)" (BI 9 grudnia 1943 roku);

- wzory sowieckie: „PPR w Kraju podkopuje, jak tylko może, autorytet legalnych władz polskich, rzucając - znowu zresztą według sowieckich wzorów - oszczerstwa na przedstawicielstwa Rządu i Sił Zbrojnych w Kraju, że wysługują się Niemcom, i tym podobne bzdury" (BI 9 grudnia 1943 roku).

Motywacja dla tego typu etykietek jest bardziej złożona, często wchodzą one w bardziej rozbudowane intertekstualne konteksty. Przykładowo, ciekawe zjawisko semantyczne ujawnia się w tekstach nurtu socjalistycznego i komunistycznego, 
w których rzeczownik okupant odrywa się od swego prymarnego znaczenia 'najeźdźca', a ze względu na aktualne odniesienie do wojennego terroru - wypełnia się treściami społecznymi obciążającymi przeciwnika politycznego ('wyzyskiwacz, żyjący kosztem drugiego'), na przykład: „Walką i pracą zmierzać będziemy do Niepodległej Ojczyzny, wolnej nie tylko od okupantów imperialistycznych, ale i okupantów finansowych wyzyskiwaczy" (Rob RPPS 10 października 1942 roku).

Wydaje się jednak, że redaktorzy prasy konspiracyjnej używają wskazanego słownictwa nie tylko po to, aby - jak wyjaśnia Irena Kamińska-Szmaj — „odbiorca zinterpretował jego [nadawcy - M.P.] komunikat jako obrażający adresata, lecz przede wszystkim po to, by podzielił jego negatywną opinię o adresacie, łączył z jego osobą emocje negatywne" (Kamińska-Szmaj 2007: 60).

W materiale źródłowym można odnaleźć również bardzo rozbudowaną siatkę pojęciową, opartą na aluzjach, ironicznych użyciach i zaskakujących znaczeniach. Takie ciekawe zjawisko pojawia się $\mathrm{w}$ artykułach porównujących propagandę komunistyczną z propagandą niemiecką. Aby ją ośmieszyć, autorzy tekstów posługują się popularnymi w uzusie okresu wojennego nazwami hitlerowskich środków komunikacji masowej (chodzi o neosemantyzmy motywowane od ironicznych lub pogardliwych nazw gebelsiki, szmatławce - 'prasa niemiecka', szczekaczki - 'megafony uliczne'), na przykład: moskiewskie "gebelsiki«: „Ale rekord pobiły moskiewskie "gebelsiki«, podając jako dowód przyjaznego do Niemiec nastawienia rządu polskiego... audycje radiostacji »Wanda «, uruchomionej, jak wiadomo, przez Niemców we Włoszech w celach dywersyjnych. Niedługo zaczną na dowód „faszystowskich sympatii” naszego narodu przytaczać zdania ze szmatławców!” (BI 6 lipca 1944 roku); szmatławce moskiewskie i szczekaczki sowieckie: „Obleśna kokieteria moskiewskich szmatławców i propagandowych szczekaczek sowieckich jest tylko dowodem pobożnych życzeń [...] kiwanego przez Anglików »Koby« [Stalina]” (Walka SN dod. 1944 rok).

\section{Dwa najważniejsze źródła inwektyw politycznych lat 1939-1945}

Analizując spory polityczne i strategie walki na słowa w podziemnym dyskursie politycznym, można dostrzec dwie podstawowe ramy dyskursu, zawierające reprezentatywne dla działalności propagandowej kategorie pojęć, etykietek i strategii o charakterze antagonistycznym, a jednocześnie agresywnym. Powstają one w obrębie publicystyki wymierzonej przeciwko: 1) PPR-owi i ugrupowaniom zbrojnym powiązanym z nurtem komunistycznym oraz 2) w obrębie publicystyki krytykującej lub szkalującej działalność rządu polskiego na uchodźstwie. Ponieważ te dwa obrazy - w świetle oglądu materiału źródłowego - można uznać za najważniejsze składniki całej politycznej narracji okresu wojennego, a przede wszystkim za eks- 
pozycję najważniejszych środków deprecjacji przeciwnika i wartościowania dychotomicznego, spróbujmy w sposób syntetyczny wskazać występujące w nich środki obrażania. Są one nie tylko znakiem retoryki walki z przeciwnikiem politycznym, lecz także ekspozycją polaryzacji całego dyskursu politycznego lat 1939-1945. Analizy warto poprzedzić uwagą porządkującą, że o ile krytyczny czy pogardliwy stosunek do działalności ugrupowań komunistycznych pojawiał się we wszystkich pismach ideowych ugrupowań wyrażających sprzeciw wobec działalności Polskiej Partii Robotniczej, o tyle negatywny, deprecjonujący obraz rządu na uchodźstwie miał zróżnicowanego nadawcę. Retoryką „antyrządową” posługiwały się dosadnie ugrupowania komunistyczne i lewicy radykalnej - szczególnie w ostatnim okresie okupacji, czyli po ich konsolidacji w ramach Krajowej Rady Narodowej (styczeń 1944 roku) - jak i wybrane ugrupowania „czwórki” (Rady Jedności Narodowej), które albo nie akceptowały udziału w rządzie koalicjantów wywodzących się z przedwojennej sanacji, albo dążyły do odsunięcia od władz na uchodźstwie „polityków wrześniowych”11.

Pierwsza grupa analizowanych przeze mnie zjawisk językowych dotyczy inwektyw skierowanych przeciwko rządowi na uchodźstwie (londyńskiemu). W określeniach negatywnych przypisywanych rządowi emigracyjnemu ujawniały się głównie sugestie o zdradzie we wrześniu 1939 roku, a także wątki rozliczeniowe. Posługiwano się odniesieniami do przeszłości przedwojennej i odniesieniami do aktualnej polityki, zarzucając władzom brak reform społecznych, autorytarny model władzy (oparty na konstytucji kwietniowej z 1935 roku), niechęć do ideologii ludowej (proletariackiej).

Składniki obrazowania władz londyńskich w perspektywie negatywnej, zbiory etykietek, sądów wartościujących pejoratywnie obrazuje poniższa tabela:

${ }^{11}$ W. Bartoszewski, charakteryzując strukturę Polskiego Państwa Podziemnego, zwraca uwagę na konfliktowe relacje w konspiracyjnym życiu politycznym; wyjaśnia, że nastąpiło „przeniesienie do podziemnego ruchu polskiego lat II wojny światowej różnego typu dawnych poglądów, metod, koncepcji taktycznych, ale i antagonizmów [...] problemy pewnych uprzedzeń politycznych, zaciekłości, walk frakcyjnych, które bynajmniej nie zdobiły, ale były prawdziwym akcentem życia w pluralistycznym państwie podziemnym, niekiedy prowadzące nawet do zjawisk eksternistycznych i godnych ubolewania, a nawet potępienia" (Bartoszewski 1987: s. 25-26). Bardziej obrazowo sytuację społeczno-polityczną okupacji przedstawia J. Chrobaczyński. Badacz zwraca uwagę przede wszystkim na rok 1943 - okres przełomowy w dziejach wojny i polityki polskiej oraz międzynarodowej. Między innymi w tym czasie zmieniał się układ sił militarnych (dyplomatycznych) na świecie, a po klęsce stalingradzkiej i rozpoczętych konferencjach koalicji antyhitlerowskiej — „Wielkiej Trójki” (Kair, Teheran) - przewidywano szybki koniec wojny. W tym czasie nastąpiły nieodwracalne pęknięcia w polskiej polityce, które przywołany historyk obrazuje w sposób następujący: „To był niewątpliwie czas sporych niepewności i wahań, polaryzacji, wreszcie autentycznej walki o władzę [...] nie tylko komuniści rozpoczęli bój o władzę, o władzę w powojennej Polsce walczyły też siły polityczne Polski »londyńskiej« oraz państwa podziemnego w okupowanym kraju. To był poważny polsko-polski spór polityczny i ideowy" (Chrobaczyński 2015: 40). 
Tabela 1. Sposoby negatywnego obrazowania władz polskich na uchodźstwie

\begin{tabular}{|c|c|}
\hline $\begin{array}{l}\text { Zespoły sądów } \\
\text { wartościujących } \\
\text { negatywnie }\end{array}$ & Przykłady realizacji tekstowych \\
\hline $\begin{array}{l}\text { 'zdrada podczas kampa- } \\
\text { nii wrześniowej i ucieczka } \\
\text { z kraju' }\end{array}$ & $\begin{array}{l}\text { - sanacyjni zdrajcy, zaprzańcy, denuncjatorzy, klęska reakcji; } \\
\text { - knowania odrodzonej targowickiej reakcji (Tr Wol } 15 \text { marca } 1944 \\
\text { roku); } \\
\text { - spadkobiercy zdradzieckiej Targowicy (Tr Wol } 15 \text { marca } 1944 \text { roku) }\end{array}$ \\
\hline $\begin{array}{l}\text { 'b a } \mathrm{n} \mathrm{k} \mathrm{r} \text { u } \mathrm{c} \mathrm{w} \text { o } \\
\text { jako synonim niskich pre- } \\
\text { dyspozycji moralnych (lub } \\
\text { ich brak); brak autorytetu } \\
\text { w okupowanym kraju, nie- } \\
\text { moralne postępowanie' }\end{array}$ & $\begin{array}{l}\text { - emigracyjny rząd bankrutów (Tr Wol } 5 \text { stycznia } 1944 \text { roku); } \\
\text { - garstka pasożytów sanacyjnych (Rob WRN } 1 \text { października } 1943 \\
\text { roku); } \\
\text { - pozbawiona oparcia w kraju, odrzucona przez Naród klika reakcyj- } \\
\text { na (Tr Wol } 2 \text { marca } 1944 \text { roku); } \\
\text { - piłsudczyzna; bankruci moralni z WRN (Rob RPPS } 26 \text { lipca } 1943 \\
\text { roku); } \\
\text { - obrońcy starego reżimu, konstytucji kwietniowej [...] podpisanej } \\
\text { drżąca ręka marszałka Piłsudskiego (WP } 16 \text { lutego } 1944 \text { roku) }\end{array}$ \\
\hline $\begin{array}{l}\text { 'rząd londyński to kon- } \\
\text { tynuacja przedwojennej } \\
\text { dyktatury, czyli sanacji' }\end{array}$ & $\begin{array}{l}\text { - zapędy imperialistyczne naszej rodzimej reakcji (Rada N. } 5 \text { marca } \\
1944 \text { roku); } \\
\text { - opanowany przez reakcję rzad emigracyjny Raczkiewiczów i Sosn- } \\
\text { kowskich (Rada N. } 23 \text { czerwca } 1944 \text { roku); } \\
\text { - stoczył się do roli wąskiej reakcyjnej kliki/do roli reprezentanta inte- } \\
\text { resów wąskiej kliki reakcyjnej (Rada N. } 5 \text { stycznia } 1944 \text { roku); } \\
\text { - dyktatura sanacyjno-ozonowa (Rada N. } 5 \text { stycznia } 1944 \text { roku); } \\
\text { - elitarno-totalistyczna konstytucja z kwietnia } 1935 \text { roku (KRN } \\
5 \text { stycznia } 1944 \text { roku); } \\
\text { - dyktatura systemu przedwrześniowego (Rada N. } 5 \text { marca } 1944 \\
\text { roku); } \\
\text { - próba wprowadzenia totalizmu z całym jego balastem frazeologii, } \\
\text { chorobliwego nacjonalizmu, wyzysku, sponiewierania godności ludz- } \\
\text { kiej (Rob RPPS } 10 \text { listopada } 1943 \text { roku) }\end{array}$ \\
\hline $\begin{array}{l}\text { 'podziały wewnętrzne, } \\
\text { nepotyzm, rozdrobnienie, } \\
\text { politykierstwo' }\end{array}$ & $\begin{array}{l}\text { - reakcyjna klika (lub częściej pluralia: reakcyjne kliki); Sosnkowski } \\
\text { i jego klika (Tr Wol } 2 \text { marca } 1944 \text { roku); } \\
\text { - klika emigrantów Sosnkowskiego, garstka reakcjonistów (Tr Wol } 15 \\
\text { marca } 1944 \text { roku); } \\
\text { - spryciarze i politykierzy, intrygi powstające wokót Naczelnego } \\
\text { Wodza (Gw Lud września } 1943 \text { roku); } \\
\text { - klika emigracyjnych zaprzańców i ich krajowych lokajów (Gł War } \\
21 \text { stycznia } 1944 \text { roku) }\end{array}$ \\
\hline
\end{tabular}




\begin{tabular}{|c|c|}
\hline $\begin{array}{l}\text { 'blokowanie działań kon- } \\
\text { spiracyjnych innych for- } \\
\text { macji politycznych, prze- } \\
\text { de wszystkim partyzantki } \\
\text { komunistycznej, ludowej, } \\
\text { które nie chcą się podpo- } \\
\text { rządkować reprezentacji } \\
\text { władz emigracyjnych' }\end{array}$ & $\begin{array}{l}\text { - reakcyjni zbrodniarze (zwykle o AK); } \\
\text { - rząd londyński i jego ekspozytury w kraju i reakcyjne partie } \\
\text { wkroczyty na bezdroża polityczne, nie widząc właściwego wroga - } \\
\text { okupanta hitlerowskiego (Rada N. } 5 \text { marca } 1944 \text { roku); } \\
\text { - chca mieć monopol na robotę wojskową (Rob RPPS } 26 \text { lipca } 1943 \\
\text { roku) } \\
\text { - elementy reakcyjne w Polsce, obserwując z nietajonym strachem } \\
\text { narastajaca fale walk partyzanckich, dawno już wyczerpaty arsenat } \\
\text { swych nieskomplikowanych „argumentów” politycznych (Tr Wol } \\
15 \text { czerwca } 1944 \text { roku); } \\
\text { - agentura krajowa reakcji (Tr Wol } 15 \text { marca } 1944 \text { roku); } \\
\text { - zdemoralizowane bezczynnością elementy „armii krajowej” (Gł War } \\
19 \text { listopada } 1943 \text { roku) }\end{array}$ \\
\hline $\begin{array}{l}\text { 'wprost prowadzą politykę } \\
\text { „antysowiecką, antykomu- } \\
\text { nistyczną" - niezgodną } \\
\text { z polską racją stanu' }\end{array}$ & $\begin{array}{l}\text { - polityka reakcji sprzeczna } z \text { wola Narodu Polskiego (Rada N. } \\
23 \text { kwietnia } 1944 \text { roku); } \\
\text { - reakcyjne i ugodowe elementy polskie (Rada N. } 5 \text { marca } 1944 \text { roku); } \\
\text { - niepoczytalna nienawiść elementów skupiajacych się wokół rządu } \\
\text { emigracyjnego (Rada N. } 5 \text { marca } 1944 \text { roku); } \\
\text { - „zamachy stanu” dokonywane przez Raczkiewiczów i Sosnkow- } \\
\text { skich (Rob RPPS } 26 \text { lipca } 1943 \text { roku) }\end{array}$ \\
\hline $\begin{array}{l}\text { 'w sprawach społeczno- } \\
\text {-ustrojowych wykazują } \\
\text { wstecznictwo' }\end{array}$ & $\begin{array}{l}\text { polskie wstecznictwo, czynniki wsteczne, polityka wstecznictwa, kam- } \\
\text { pania wstecznictwa polskiego }\end{array}$ \\
\hline $\begin{array}{l}\text { 'o politykach i ugrupowa- } \\
\text { niach zbrojnych reprezen- } \\
\text { tujących rząd emigracyjny' }\end{array}$ & $\begin{array}{l}\text { sanacyjna klika z ozonowym tak zwanym petnomocnikiem rządu na } \\
\text { czele; sanacyjna agentura } w \text { Polsce }\end{array}$ \\
\hline
\end{tabular}

Źródło: opracowanie własne.

Cechą wyróżniającą tekstów, z których pochodzi materiał językowy, jest niezwykle powszechne użycie połączeń leksykalnych z przymiotnikiem sanacyjny w znaczeniu wtórnym, wychodzącym poza związki semantyczne z przedwojennym nazewnictwem dotyczącym Obozu Zjednoczenia Narodowego (Ozonu) (zob. Karamańska 2007; Dubisz 2007), na przykład: panowie sanacyjni, naleciałości sanacyjne i faszystowskie, terror i korupcja sanacyjna, sanacyjni macherzy, odprysk sanacyjny, sanacyjna dyktatura, garstka pasożytów sanacyjnych, sanacyjna agentura ( $w$ Polsce), sanacyjne kliki wojskowe, sanacyjni przywódcy i ich pachołki $w$ Polsce.

Warto podkreślić, że leksemy typu sanacja, sanacyjny, a także pojawiający się obok nich wyraz reakcja (i jego derywat reakcyjny) stają się etykietkami politycznymi, gdyż w oderwaniu od desygnatów zaczynają funkcjonować jako synonimy różnych zjawisk konotujących negatywną ocenę. Słownictwo to - przede wszystkim w języku powojennej propagandy - stało się podstawowym wyposażeniem arbitralnych znaczeń o zabarwieniu negatywnym, a także leksykalnym składnikiem szablonowych haseł, połączeń frazeologicznych odzwierciedlających rytualizację języka polityki (por. Ożóg 2014; Nowak 2002). 
Druga grupa obejmuje inwektywy wymierzone przeciwko ugrupowaniom komunistycznym. W tekstach deprecjonujących PPR, służących pomniejszaniu roli ruchu komunistycznego lub degradacji tego ugrupowania, pojawiają się przede wszystkim liczne tezy wskazujące próbę przejęcia władzy w Polsce kosztem konstytucyjnych władz polskich i ugrupowań o rodowodzie lewicowym. Autorzy publicystyki antykomunistycznej uznają działalność PPR-u za nielegalną i zagrażającą władzom londyńskim, a także siłom zbrojnym (politycznym) w okupowanym kraju, skupionym wokół Armii Krajowej oraz wokół najważniejszych struktur politycznych państwa podziemnego. Aksjologię jednak wyznacza implikacja, że PPR, działająca w Polsce od 1942 roku, prowadzi działalność dywersyjną i politykę na rzecz ZSRR. W 1944 roku — gdy na scenie politycznej pojawia się Krajowa Rada Narodowa pod przywództwem Bolesława Bieruta, a także wyrazista staje się polityka Stalina wobec przyszłych losów Polski - negatywny obraz przyjmuje postać bardziej nacechowaną.

Co więcej, w obrazie Polskiej Partii Robotniczej i lewicy radykalnej pojawia się przede wszystkim słownictwo odnoszące się do świata ideologii i tradycji komunistycznej - leksyka ta z kolei (wraz z kluczowymi wyrazami komunizm, komunistyczny) jest świadomie pomijana w programach ideowych, artykułach publicystycznych oraz nominacjach stosowanych przez działaczy komunistycznych (por. Kamińska-Szmaj 2014; Mazur 2011).

Kolejna uwaga dotyczy autorstwa tekstów propagandowych deprecjonujących PPR. Otóż najbardziej emotywne środki językowe ujawniają się w tekstach endecji i skrajnej prawicy, natomiast ironiczne pochodzą z publikacji wydawanych przez Armię Krajową, świat lewicy wojennej i ludowców (szczególnie po przejęciu obowiązków premiera przez Stanisława Mikołajczyka, przedwojennego działacza stronnictw ludowych).

Autorzy różnych stronnictw politycznych posługują się między innymi następującymi środkami deprecjacji, ujawniającymi się w argumentacji sugerującej/orzekającej (zob. Tabela 2).

Za charakterystyczne zjawisko należy uznać użycie leksemów odnoszących się do świata komunizmu jako synonimów przymiotników sowiecki i bolszewicki. Z jednej strony w publicystyce ujawnia się słownictwo przedwojenne, używane w latach dwudziestych i trzydziestych jako określenia tak Kominternu, jak i Komunistycznej Partii Polskiej (KPP), z drugiej strony zaś powracają wtórne realizacje stereotypu propagandowego 'bolszewika' (Kamińska-Szmaj 1994; Jaeschke 2002) oraz ideologicznie motywowane użycia przymiotnika sowiecki - 'dotyczący Sowietów, ros. rad' - odrywające ten leksem od kontekstów związanych z nazwą własną Związek Sowiecki (por. Język polski czasu... 1996; Ostaszewska 1996). Oba leksemy tworzą połączenia z wyrazami: agentura, działalność (propagandowa), agitacja. 
Tabela 2. Sposoby negatywnego obrazowania ruchu komunistycznego (PPR-u) - opracowanie własne.

\begin{tabular}{|c|c|}
\hline $\begin{array}{l}\text { y sądów } \\
\text { ciujących } \\
\text { cywnie }\end{array}$ & Przykłady realizacji tekstowych \\
\hline $\begin{array}{l}\text { 'ugrupowanie komunistycz- } \\
\text { ne (PPR, KRN, partyzantka), } \\
\text { a także instytucje działające } \\
\text { w ZSRR (Związek Patrio- } \\
\text { tów Polskich oraz I Dywizja } \\
\text { im. T. Kościuszki gen. Z. Ber- } \\
\text { linga)' }\end{array}$ & $\begin{array}{l}\text { - [PPR]: tzw. „Polska Partia Robotnicza” (BI } 20 \text { kwietnia } 1943 \\
\text { roku); } \\
\text { - partia rosyjska wylęgła pod obcym skrzydłem (odezwa PPS, SL } \\
24 \text { lipca } 1944 \text { roku); } \\
\text { - PPR znaczy też: Partia Przyjaciół Rosji, nie ma w niej ani jedne- } \\
\text { go przyjaciela Polski (Gł Lud } 1 \text { grudnia } 1943 \text { roku); } \\
\text { - towarzysze (czytać należy towaryszczy) zPPR (Gł Lud } 28 \text { kwiet- } \\
\text { nia } 1943 \text { roku); } \\
\text { - tzw. Polska Partia Robotnicza - nowa agentka moskiewskiego } \\
\text { Kominternu (BI } 2 \text { lipca } 1943 \text { roku); } \\
\text { - [ZPP]: działalność agentów sowieckich i komunistycznych spod } \\
\text { znaku tak zwanego Związku Patriotów Polskich, PPR-u, różnych } \\
\text { oszustów (Gw Lud 1943, nr 7); } \\
\text { - Związek Patriotów Polskich - to patrioci z „musu” (Gł Pol } \\
28 \text { maja } 1944 \text { roku); } \\
\text { - [KRN, PKWN]: krajowa zd-Rada Narodowa (Gł Lud } 1 \text { grudnia } \\
1943 \text { roku); } \\
\text { - Sowiety powołały dywersyjny rzad polski, którego zadaniem ma } \\
\text { być pełnienie obowiazkków rządu w Polsce (BI } 27 \text { lipca } 1944 \text { roku); } \\
\text { - twór PPR-u, sowieckiej agentury w Polsce (BI } 27 \text { lipca } 1944 \\
\text { roku); } \\
\text { - sowiecki Komitet wyzwolenia Polski (BI } 27 \text { lipca } 1944 \text { roku) }\end{array}$ \\
\hline $\begin{array}{l}\text { 'ugrupowanie prowadzące } \\
\text { dywersję na rzecz ZSRR, roz- } \\
\text { bijające między innymi pol- } \\
\text { skie podziemie' }\end{array}$ & $\begin{array}{l}\text { - sowiecka piata kolumna (Gł Ludu } 1 \text { grudnia } 1943 \text { roku); } \\
\text { - V kolumna imperializmu rosyjskiego (BI } 7 \text { października } 1943 \\
\text { roku); } \\
\text { - „jaczejki PPR” i „czerwoni volksdeutsche” (Sz } 1 \text { stycznia } 1943 \\
\text { roku) }\end{array}$ \\
\hline $\begin{array}{l}\text { 'działają przeciwko władzom } \\
\text { polskim, są agentami obcego } \\
\text { mocarstwa' }\end{array}$ & $\begin{array}{l}\text { - agenci Moskwy, poszli na lep komunizmu (Rob w walce } 1 \text { paź- } \\
\text { dziernika } 1943 \text { roku); } \\
\text { - agenci Moskwy w PPR (Wieś i M. wrzesień } 1943 \text { roku); } \\
\text { - obca agentura pod firma/ szyldem PPR (BI } 10 \text { lutego } 1944 \text { roku); } \\
\text { - bandy PPR, agentura sowiecka, przygotowuje Polske na wzór } \\
\text { władzy czerwonej (Gł Lud } 1 \text { grudnia } 1943 \text { roku); } \\
\text { - agenci bolszewiccy; towarzysze z PPR! (Gł Lud } 28 \text { kwietnia } 1944 \\
\text { roku); } \\
\text { - idzie wielka robota komunistyczna w Polsce... i przeciw Polsce } \\
\text { (BI } 23 \text { września } 1943 \text { roku) }\end{array}$ \\
\hline
\end{tabular}




\begin{tabular}{|c|c|}
\hline $\begin{array}{l}\text { 'nadużywają haseł patrio- } \\
\text { tycznych, choć działają w in- } \\
\text { teresie propagandy sowie- } \\
\text { ckiej' }\end{array}$ & $\begin{array}{l}\text { - hasła swe i metody pracy PPR zmienia odpowiednio do haset } \\
\text { i metod pracy i rzadu sowieckiego (BI } 9 \text { grudnia } 1943 \text { roku); } \\
\text { - rozwijają bardzo żywą i gorliwą agitację komunistyczna i usiłuja } \\
\text { wzbudzić przychylność ludności dla Sowietów (BI } 16 \text { czerwca } 1943 \\
\text { roku); } \\
\text { - stosuja jako przynętę „reakcyjna frazeologię” (Walka } 1944 \text { rok); } \\
\text { - Maskując swe istotne cele [...] obłudnie nadużywanymi hasłami } \\
\text { patriotycznymi, narodowymi, komunistyczna „Polska Partia Robot- } \\
\text { nicza” w rodzaju rzekomo „Polskiej” Armii Ludowej (BI } 10 \text { lutego } \\
1944 \text { roku) }\end{array}$ \\
\hline $\begin{array}{l}\text { 'przygotowują nowy ustrój } \\
\text { polityczny w Polsce' }\end{array}$ & $\begin{array}{l}\text { - chwyty komunistyczne mające na celu łapanie w sidła naiwnie } \\
\text { politycznych ludzi (BI } 16 \text { września } 1943 \text { roku); } \\
\text { - wytarte chwyty agitacji bolszewickiej, obliczone chyba na zanik } \\
\text { pamięci lub pelną głupotę czytelnika (BI } 2 \text { lipca } 1942 \text { roku) }\end{array}$ \\
\hline
\end{tabular}

Źródło: opracowanie własne.

\section{Językowe środki deprecjonowania przeciwnika/wroga politycznego w prasie konspiracyjnej lat 1939-1945. Przegląd najważniejszych zjawisk i strategii}

7.1. Na ogół rywal polityczny jest poniżany lub lżony za pomocą środków leksykalnych prymarnie (systemowo) lub wtórnie (konotacyjnie, kontekstowo) wartościujących. W nominacjach agensa lub nosiciela cechy uznawanej za pejoratywną, zasługującej na potępienie, pojawiają się głównie leksemy, które wywodzą się z pola semantycznego opisującego 'zdradę, postawę wrogości, działalność zagrażającą państwu'. Adresat inwektywy to często: szkodnik, zbrodniarz, szaleniec, zdrajca, zaprzaniec, renegat, sprzedawczyk, najmita, oszust, szalbierz, denuncjator, zakała, pasożyt, pachołek, spekulant, intrygant (polityczny), warchoł. Jako synonimy wymienionych leksemów - niemalże w sposób nieograniczony - pojawiają się rzeczowniki typu agent, wróg (+ jakiś: śmiertelny lub czegoś: ludu, narodu itp.), agitator (komunistyczny).

Rywalowi politycznemu przypisuje się zachowania uznawane za niegodne za pomocą:

- rzeczowników z kategorii nomina actionis/essendi, takich jak: bandytyzm, dywersja, prowokacja, machinacja, knowania - szczególną semantyczną „siłę” ma leksem agentura - odpowiednio kwalifikujący potępiane działanie polityczne, lecz używany w funkcji nazwy kolektywnej (czyli wzmacniającej wyobrażenie na temat zbiorowości politycznej/ideologicznej), na przykład: agentury moskiewskie, sowieckie, komunistyczne, Kremla - agentury rzadu emigracyjnego, krajowe agentury rzadu londyńskiego; 
- rzeczowników konotujących obraz przeciwnika, któremu przypisuje się zamiar degradacji państwa, na przykład: warcholstwo, bezprawie, politykierstwo, bankructwo, awanturnictwo, pasożytnictwo, barbarzyństwo, kunktatorstwo, matactwo.

Wśród rzeczowników pojawia się wiele nazw i określeń zbiorowości, grupy społecznej, politycznej, ale nadawcy, wykorzystując konotacje zawarte w semach 'wielkość-małość, presuponują jednocześnie sąd, że można ją uznać za groźną lub po prostu zlekceważyć. Niekiedy taką funkcję pragmatyczną komunikatów wyraża ironia zawarta $\mathrm{w}$ formach deminutywnych lub kolektywnych, na przykład: (reakcyjna/londyńska) klika; garstka (reakcyjnych bankrutów); (barbarzyńska) dzicz; grupy i grupki (partyjne); kołtuneria; łobuzeria; agentura; mafia; rodzina; rodzinka (partyjna).

W materiale źródłowych dostrzec można również procesy semantyczne, które polegają na przesuwaniu nazw wywodzących się z pola leksykalnego określającego politykę, ideologię na poziom znaczeń ogólnych. Zjawisko to ilustrują „wojenne losy" leksemów reakcja/reakcyjny, sanacja/sanacyjny, wstecznictwo, które w aktach deprecjacji funkcjonują jako synonimy lub substytuty nazewnicze różnych innych zjawisk negatywnych o niedookreślonej referencji, por.: polityka wstecznictwa, polskie wstecznictwo, czynniki wsteczne, waska reakcyjna klika, sanacyjne kliki i kliczki ${ }^{12}$ itp. Stają się za to wyrazistymi etykietkami politycznymi (por. Kochan 1994; Nowak 2002), gdyż pojawiają się w kontekstach znaczeniowych (tekstowych) przypisanych określonej grupie politycznej - $\mathrm{w}$ tym wypadku działaczom politycznym przedwojennym lub emigracyjnym. Zwykle słownictwo to pojawia się w prasie lewicowej, od 1943 roku jego „zagęszczenie” można odnaleźć w gazetach partii komunistycznej. Słowa te nabywają właściwości pragmatycznych etykietek z tego powodu, że użycie w tekście publicystycznym pojedynczych leksemów typu reakcja, klika, sanacja jest warunkiem wystarczającym, aby odnieść je do konkretnego adresata inwektywy, czyli do środowisk „prorządowych/antykomunistycznych”. W takiej też szablonowej postaci przejdą one do zbioru podstawowych wyrazów obraźliwych wykorzystywanych w późniejszej propagandzie PRL-u (por. Nowak 2002; Dytman-Stasieńko 2006), a także staną się podstawą arbitralnych znaczeń i rytuałów, szablonów językowych propagandy powojennej (por. Ożóg 2014).

Większość leksemów pojawia się w formach tekstowych pluralnych — szczególnie nieograniczony zasięg konotacji pejoratywnych, a jednocześnie odbierających cześć adresatowi aktu deprecjacji, wykazuje użycie leksemu element wraz z różnymi ciągami określeń, na przykład: elementy $+z$ dradzieckie, antypolskie, antyludowe, antydemokratyczne, zbrodnicze, niepolskiego pochodzenia, także $\mathrm{w}$ aspekcie ideologicznym: zdegradowane elementy polskiej reakcji, $w$ atmosferze zbrodniczego rozpa-

12 Semantyczną analizę leksemu „klika” można odnaleźć w artykule A. Pajdzińskiej (2008), natomiast o przedwojennych dziejach wyrazu „reakcja”, pochodzącego z dziewiętnastowiecznego języka publicystyki prasowej (głównie o rodowodzie lewicowym, socjalistycznym), a jednocześnie jednego z najbardziej rozmytych pod względem znaczeniowym słów polemiki politycznej lat trzydziestych XX wieku, więcej M. Karamańska (2007). 
sania najbardziej zwyrodniałych elementów, elementy reakcyjne i ugodowe, elementy polskie, skupiajace się wokół obozu sanacyjnego.

$\mathrm{W}$ obrębie epitetów sytuują się przede wszystkim leksemy przymiotnikowe nacechowane emotywnie-oceniająco, które wartościują negatywnie cechy przeciwnika/ wroga w aspekcie etycznym ('nieprawość, oszustwo'), społecznym ('obcość, wrogość), a także intelektualnym. Przymiotniki często pojawiają się w dłuższych ciągach (syntagmach) nominalnych, niekiedy nawet redundantnych pod względem aksjologicznym w stosunku do znaczeń/semów zawartych w rzeczownikach, których są określnikami. Oto dość charakterystyczne użycia wynotowane z prasy o różnych obliczach ideologicznych: wrogi (+ czemuś: narodowi), obcy (+ agenci, agentura), bestialski, zbrodniczy, zwyrodniały, nikczemny, plugawy, obłudny, przebiegty, chytry, chytry (plan), dziki, bezmyślny, bałamutny, kłamliwy, zdradziecki. Jako epitety pojawiają się też pokrewne semantycznie imiesłowy bierne predykatów (z)bankrutować, zdemoralizować, $z$ degenerować, a nawet neologizm (s)totalizować -'całkowicie/ podporządkować coś czemu na wzór reżimów totalnych/ totalitarnych'

Opisując działalność grupy politycznej, zasługującej według nadawcy na potępienie, używa się predykatów ekspresywnych, niekiedy wywodzących się z polszczyzny potocznej (kolokwialnej). Czasowniki bardzo często występują w użyciach sekundarnych, stając się składnikami innowacji frazeologicznych lub połączeń leksykalnych o znaczeniach metonimicznych, obrazowych. W tej funkcji stosuje się głównie predykaty z semami 'kłamać, 'manipulować, 'zdradzać kogoś', 'szkodzić komuś, jak na przykład: denuncjować, kłamać, łżeć, podjudzać, bałamucić, knuć, kumać się, bluffować. Wskażmy w tym miejscu kilka emotywnych przykładów predykatów wykorzystanych w funkcji słownictwa sekundarnie wartościującego. Chodzi o czasowniki typu: hulać, hasać, przyoblec się, snuć się, wżerać się itp. Słownictwo to pojawia się między innymi w następujących kontekstach metaforycznych - w funkcji personifikacji działań opozycyjnych partii, środowisk konspiracyjnych (zob. pkt 1) lub w funkcji animizacji abstrakcyjnych zjawisk z życia politycznego (zob. pkt 2): 1) krwawo hulać ('przemoc'): „[NSZ] zaczął krwawo hulać, usuwając wszelkie przeszkody, jakie napotyka polski faszyzm” („Robotnik” RPPS 16 maja 1944 roku); hasać ('bawić się): „Polska reakcja w Londynie hasa” („Barykada Wolności” 30 marca $1941 \mathrm{roku}$ ); przyoblec się $w$ różne szaty ('ukrywać swoje zamiary polityczne'): „szlachetczyzna przyoblekająca się w szaty różnorakich polskich faszystów i związanych z tym dyktatur” („Żywią i Bronią” marzec 1942 roku); 2) snuć się: „w oparach jadu i żółci snuje się niedwuznaczny podstępny zamiar” („Żywią i Bronią" maj 1942 roku); wżerać się: „w umysły wodzów SL wżarła się oenerowsko-sanacyjna ideologia” („Głos Warszawy” 14 marca 1944 roku).

7.2. Właściwością badanego materiału leksykalnego jest tendencja do intensyfikacji odczuć, wrażeń, emocji za pomocą rozbudowanych struktur składniowych (głównie nominalnych). Służą one hiperbolizacji, wyolbrzymieniu zjawisk uznawanych za pejoratywne. Negatywizm wprowadzają przede wszystkim szeregowe połączenia rzeczowników i przymiotników (imiesłowów przymiotnikowych), co spra- 
wia, że znaczenia nie są precyzyjne, ale sama klasyfikacja oceny — redundantna, zwielokrotniona. Niekiedy podobny efekt występuje w złożeniach (kompozycjach) utworzonych od różnych podstaw przymiotnikowych, rozbudowanych strukturalnie po to, aby wzmocnić ich funkcje stylistyczne (na przykład epitetu) - por.: prowokacja i oszczerstwo, podłość i łajdactwo, szpiclostwo i zakłamanie, zbrodnia i prowokacja, wściekłość i nienawiść, haniebny i potworny, obłędny i szkodliwy, złowrogi i okrutny, gorszace i szkodliwe (działania/wyczyny/akcje), donosicielsko-prowokacyjny, łgarstwo na łgarstwie, szczyt szczytów, złodzieje i bankruci, warchoły i maniaki, oszczercy i kalmuniatorzy, sprzedawczykostwo i nieprawości (wszelakie). Dobór syntagm nominalnych jest szeroki - zwykle leksyka prymarnie wartościująca wchodzi w bogatsze znaczeniowo konteksty; staje się epitetem dla pojęć odwołujących się do nazewnictwa politycznego, ideologicznego - przez to nie orzeka o samej cesze pejoratywnej, lecz o właściwościach pojęcia, któremu jest przypisana - na przykład: obcy agenci i obałamucone przez nich jednostki, intryganci sanacyjni $i$ ich trabanci $z$ frontu belwederskiego, zdziczałe barbarzyństwo $i$ zdziczenie powszechne, zapędy imperialistyczne naszej rodzimej reakcji, knowania odrodzonej targowickiej reakcji.

7.3. Słownictwo wtórnie wartościujące pozwala wywoływać różne konotacje emotywno-oceniające, a przede wszystkim aktualizować sądy, stereotypy, schematy mentalne towarzyszące polemikom. Z jednej strony wyostrza się obraz przeciwnika/ wroga politycznego, z drugiej zaś poszerza się pragmatyczny i semantyczny zakres postaw wobec aktualnych wydarzeń politycznych. Jak pisze Irena Kamińska-Szmaj, cechą znaczeń konotacyjnych jest to, że

wtórne znaczenia przypisywane wyrazom funkcjonują jedynie w obrębie danej wspólnoty komunikatywnej, a nacechowanie emocjonalno-aksjologiczne leksemów czy całych wyrażeń wynika ze znaczeń uzgodnionych, odzwierciedlających stosunek tej grupy społecznej (użytkowników języka) do rzeczywistości pozajęzykowej (w tym społeczno-politycznej) postrzeganej przez pryzmat wyznawanych wartości, akceptowanych lub nieakceptowanych ideologii. (Kamińska-Szmaj 2007: 64)

Analizowane przykłady pozwalają postawić tezę, że w polemikach politycznych okresu wojennego stabilizuje się wiele kolokacji przypisujących przeciwnikowi cechy wroga poprzez utożsamianie jego działalności z metodami charakterystycznymi dla państw totalitarnych (por. Jaeschke 2002) lub poprzez aluzje do czasów (rządów) sprzed 1939 roku. Negatywne konteksty ma wzbudzać użycie przymiotników odnoszących się do pojęć politycznych, ideologicznych takich, jak: reakcyjny, sanacyjny, endecki, faszystowski, hitlerowski, komunistyczny, sowiecki (rzadziej germański, bolszewicki, kominternowski, czerwony, brunatny), także imperialistyczny i obszarniczy — wraz z rozbudowanymi określeniami/kolokacjami (niekiedy obejmujących nawet kilka składników):

— agenci + (wymiennie) obcego imperializmu/hitleryzmu/kominternowscy, agent hitleryzmu/komunizmu;

- wspótpraca $z+$ (wymiennie) sowieckimi/moskiewskimi/hitlerowskimi/gestapowskimi mocodawcami; 
- podstępna propaganda komunistyczna, propaganda Kominternu, propagandowe jaczejki komunistyczne, hitlerowskie metody propagandowe;

- kremliński/sowiecki + Związek Patriotów Polskich, kremlińscy/moskiewscy + patrioci, agentury NKWD;

- hitlerowsko-faszystowska dyktatura, hitlerowska agentura, żywioł reakcyjno-faszystowski, póthitleryzm, mentalność hitlerowska, faszystowskie knowania, faszystowskie kliki reakcyjne, polscy esesowcy, gestapowskie metody, niemiecki pachołki, nasi rodzimi faszyści, żywiot reakcyjno-faszystowski, polscy faszyści w stużbie okupanta, orientacja proniemiecka;

- uzurpatorzy emigracyjni w Londynie, sanacyjne knowania spiskowe.

W niektórych tekstach publicystycznych badanego okresu pojawiają się również epitety, których podstawą są konotacje odwołujące się do stereotypu propagandowego Żyda (por. Kamińska-Szmaj 1994), albo też środki językowe wykorzystujące klisze wywodzące się z przedwojennej mowy nienawiści, odzwierciedlające retorykę antysemicką (por. Cała 2012; Kowalski, Tulli 2003; Michlic 2015). Autorzy tekstów publicystycznych wydawanych w prasie nacjonalistycznej i oenerowskiej („Szaniec”, "Naród”) w celu szkalowania działań i programów politycznych strony przeciwnej (głównie ugrupowań lewicowych i komunistycznych) dość często wykorzystują wyrażenia typu: modły żydowskie, klątwa rabinacka, fanatyczne źrenice starozakonne, Judeo-Polska, światowe żydostwo, kapitał anglo-żydowski, żydek Berling/Berlinger itp.

7.4. Publicyści, sięgając po różne środki, które mają za zadanie utrwalać presupozycję 'adresat inwektywy postępuje jak okupant/wróg zewnętrzny', posługują się również peryfrazami opartymi na modyfikacjach lub kontaminacjach znaczeniowych (na przykład zaprzedajni wielbiciele Stalina, rzad polski imieniem tow. Stalina, płatne pachołki Moskwy, komuniści mianujący się polskimi, czerwoni volksdeutsche).

Niektóre wyrażenia peryfrastyczne mają za zadanie utrwalać aluzje, a częściej wzbudzać szyderczy humor lub ironię. Przykładami są następujące środki leksykalne: muszkieterowie w obronie naszego staropolskiego "liberum veto" ('o ministrach wywodzących się z sanacji'); szkodliwe nałogi myślowe nad Tamiza ('polityka rządu londyńskiego'); kochankowie Wielkiej Niedźwiedzicy ('politycy PPR-u'); frazesy naładowane dynamitem ('apele, hasła mobilizacyjne zawarte w publicystyce strony przeciwnej'); delegatury z ducha szlachetczyzny poczęte; pogrobowcy dawnej szlachetczyzny; pańszczyźniany kompleks niższości; uciekający panicze z płonącej Ojczyzny, Rzesza Sanacyjna $\leftarrow$ (Trzecia) Rzesza + Sanacja ('o politykach utożsamianych z rządami II RP'). Omówienia często powstają na skutek przekształcenia nazwy własnej (nazwisk działaczy politycznych, nazw partii politycznych lub onimów skojarzonych z wydarzeniami bieżącymi lub historycznymi), na przykład: PKWN - Sowiecki Komitet Wyzwolenia Polski; KRN - rozbijacka rada narodowa, krajowa zd-rada narodowa; przeciw-rząd Targowicy. W tej grupie pojawiają się także nazwiska polityków, przywódców państw europejskich, którzy uznawani byli za kolaborantów Trzeciej Rzeszy, na przykład: polscy Quislingowie/Hachowie. 
Aby ośmieszyć przedstawicieli opozycyjnych ugrupowań podziemnych, sięgano także po znaczenia polisemiczne związane $\mathrm{z}$ wyrazem pan (także po jego derywaty). Raz pojawiał się on jako znak „pozorowanej grzeczności”, raz jako leksem $\mathrm{w}$ znaczeniu władca, a więc pozwalający w formie ironicznej pomniejszyć rangę, godność osoby czy grupy politycznej, o której nadawca orzeka w sposób podniosły. Połączenia wyrazów panowie, panicze, paniczyki - wraz z określeniami uznawanymi przez nadawcę za pejoratywne - prymarnie wyostrzały sarkastyczny ton aktu deprecjacji, na przykład: panowie sanatorowie - o politykach sanacji; jaśnie panowie $z$ endecji, paniczyk z ONR-u - a sekundarnie, szczególnie w piśmiennictwie lewicowym, zawierały dodatkowe aluzje o charakterze socjalnym (ideologicznym), na przykład: „Krzykliwym „paniczom” narodowo-radykalnym aż iskrzą się oczy, by sięgnąć na wieś” („Żywią i Walczą” grudzień 1942 roku); „Panicze z ONR-u niech się nie wygłupiają [...], bo robociarze polscy [...] połamią paniczom z ONR-u kości” („Robotnik” 20 czerwiec 1942 roku).

7.5. Publicyści prasy konspiracyjnej posługują się również licznymi modyfikacjami tradycyjnych frazeologizmów lub innowacyjnymi połączeniami wyrazowymi (mord skrytobójczy, drużyny kainowe, zdradzieckie knowania). Mają one często charakter doraźny i metaforyczny, a za cechę wspólną należy uznać to, że głównie odnoszą się do realiów polityczno-okupacyjnych, czyli sytuują się w polach semantycznych dotyczących działalności propagandowo-zbrojnej przeciwnika/rywala. Wykorzystuje się je, aby wzmocnić pejoratywny obraz opozycyjnych ugrupowań, a przede wszystkim pomniejszyć lub ośmieszyć znaczenie metod propagandowych, środków perswazji, stylu wypowiedzi czasopism strony przeciwnej. Oskarża się opozycyjne partie i grupy konspiracyjne o działania na szkodę Polski (przykłady z grupy 1.) lub przypisuje obcej propagandzie cechy komunikacji politycznej opartej na agitacji, manipulacji, oszustwie (przykłady z grupy 2.): 1) kierować nóż bratobójczy; zadawać skrytobójczy cios; podpisywać wyrok na niepodległość Polski; prowadzić krecie podkopy pod autorytetem obecnego Rządu Polskiego; żerować w imię interesów obcego mocarstwa; poczuć w sobie krew niemiecką; sprzedawać się sanacji za miskę soczewicy; przybierać nowe szaty/szyldy partyjne; zastawiać sidła; warcholić i podziemnie się podgryzać; knuć spisek; 2) frymarczyć wielkimi słowami; otumaniać patriotycznym frazesem; maskować swe wystapienia "patriotycznymi” i „narodowymi” hasłami; urabiać patriotycznie naród; poruszać w ruch aparat hasel hurrapatriotycznych; stare prawdy przeplatać zatrutym fatszem; siać zamęt w umysłach dość skarlałych; szarpać się jak pies na łańcuchu; wyładowywać się w polemikach; wyrzucać $z$ siebie jad; wykręcać się sianem; mieszać $z$ błotem $X$-a; spuszczać gromy; z uporem maniaka powtarzać tę sama śpiewkę; pisać rękq zawodowych prowokatorów; szczuć wojna, jechać kłamstwami; prześcigać nawet prasę hitlerowska w pisaniu bredni wyssanych z palca; bluźnierczo szafować imieniem $X-a$; wyrzucać na śmietnik niejedna świętość; zanurzać się w cuchnącym bagnie.

Wiele z leksemów i frazeologizmów wywodzących się ze stylistyki potocznej, ujawniających antropocentryczne wzorce konceptualizacji świata, przedstawia świat 
napięć politycznych w perspektywie konkretu, a tym samym wykazuje wysoki potencjał do metaforyzacji i metonimizacji, por.: „Długa sążnista argumentacja wywlokła wszystko, co w reakcyjnych głowach wylęgło się w ciągu ostatnich lat” („Głos Warszawy” 11 lutego 1944 roku); „Rada Jedności wykrztusiła w deklaracji pusty frazes” („Robotnik” RPPS 1 maja 1944 roku); „z pianą na ustach wymyśla i lży chłopskich uczestników w rządzie gen. Sikorskiego” („Żywią i Bronią” marzec 1942 roku); „Nowe pisemko sanacyjne zaczęło się irytować” („Żywią i Walczą” grudzień 1943 roku); „Jak dotąd WRN atakował nas zza płota, nie wymieniając po imieniu, ale za to obrzucając najgorszymi paszkwilami” („Robotnik” 6 czerwca 1942 roku); „bezkarność, z jaką rozbójnicy prasowi uprawiają swoją robotę” („Głos Warszawy” 21 kwietnia 1944 roku).

Obok leksyki antropomorficznej, antropocentrycznej pojawiają się konteksty znaczeniowe przenoszące wypowiedź w przestrzeń komunikacji negatywnej (termin Sarnowskiego 1999) z tego powodu, że intencjonalny zamiar obrażania eksplikowany jest za pomocą słownictwa wulgarnego lub naruszającego tabu. Świadczą o tym chociażby metafory odwołujące się do sfery ludzkich zachowań fizjologicznych czy nawet seksualnych: [prasa lewicy radykalnej o konsolidacji sił zbrojnych ludowców pod zwierzchnictwem AK ] „Wiele zabiegów i intryg musiała wykonać sanacja, żeby zgwałcić Bataliony Chłopskie do podporządkowania się sanacyjnej komendzie ZWZ (AK)” („Robotnik” RPPS 16 maja 1944 roku); [prasa narodowców o Związku Patriotów Polskich] „Taki jest rodowód »związku patriotów polskich « w Moskwie poczętych $z$ matki »Russia« i ojca... Stalina” („Głos Polski” 28 maja 1944 roku).

7.6. W publicystyce konspiracyjnej pojawiają się również typowe dla perswazji językowej, jak i języka propagandy politycznej środki werbalne z poziomu morfologicznego. Między innymi w funkcji synekdochy stosuje się gramatyczne formy deprecjatywne lub pluralne nazwisk działaczy politycznych, jak na przykład: Sosnkowscy, Rydzowie, Raczkiewicze, Beckowie, Składkowscy. Wyrazem kreatywności językowej, a jednocześnie intencjonalnych (pragmatycznych) działań zmierzających do zdegradowania rywala politycznego, do zaznaczenia opozycji dychotomicznej MY-ONI, okazują się zabiegi językowe o charakterze słowotwórczym (por. Kudra 2001). W materiale językowym można odnotować całe serie derywatów lub quasi-złożeń, za pomocą których neguje się, pomniejsza pojęcia dotyczące świata polityki i ideologii reprezentowanej przez „wroga” albo przypisuje się im znaczenia sprzeczne z rzeczywistymi. Służą do tego przede wszystkim prefiksy: 1) anty-/przeciw-: antypolski, antyludowy, antydemokratyczny, antykonsolidacja (przeciw zjednoczeniu Kraju), przeciwpolski, przeciw-rzad (Targowicy); 2) pro-: prohitlerowski, prosowiecki (rzad polski w Kraju), prokomunistyczny; 3) pseudo-: pseudo-demokracja, pseudo-patriotyzm, pseudo-rzad, pseudo-radykalny i pseudo-demokratyczny, pseudo-bojowy, pseudo-robotniczy.

Występują również żartobliwe neologizmy typu urzędówki i półurzędówki, rzadziciele oraz seria wyrazów z podstawą hurra-: hurra-patriota ( $\rightarrow$ hurra-patriotyczny), (sarmacki) hurra-patriotyzm, hurra-komunista - derywaty te używane są głównie w znaczeniu ironicznym. Natomiast pragmatyczny wymiar technik słowotwórczych 
odnaleźć można w neologizmach motywowanych od nazw ugrupowań politycznych, nurtów ideologicznych, skrótów i akronimów partii politycznych oraz nazwisk znanych polityków. Opisane zabiegi językowe ilustrują między innymi następujące leksemy/derywaty: dmowszczyzna, piłsudczyzna, sikorszczyzna, obóz belwederski $\rightarrow$ belwederczyk (sławetni panowie belwederczycy); WRN (wueren) $\rightarrow$ wuenerowy; ZWZ $\rightarrow$ zwztowski (zetwuzetowscy kalumniańci); Obóz Zjednoczenia Narodowego (Ozon) $\rightarrow$ ozonizacja, ozonista (panowie ozoniści). Niektóre z nich - przyjmujące głównie postać kontaminacji lub kompozycji - używane są po to, aby powiązać w jedną strukturę wyrazową pojęcia pogardzane przez nadawcę aktu inwektywy (sanacyjny + ozonowy) lub połączyć znaczenia nienacechowane wartościująco ze znaczeniami prymarnie negatywnymi (elitarny + totalistyczny), a także je wzmocnić (sanacyjny + faszystowski), por.: endecja (SN) + oener (ONR) $\rightarrow$ endo-oenerowski; endecja + sanacja $\rightarrow$ endo-sanacja ( $\rightarrow$ endosanacyjna $A K$ ); sanacyjno-ozonowskilozonowy, elitarno-totalistyczny, sanacyjno-faszystowski. Bardzo często wybrane derywaty przymiotnikowe funkcjonują w tekstach w funkcji rzeczowników (w formach liczby mnogiej), stając się tym samym środkiem wyrażania synekdochy przedstawiającej obraz przeciwnika jako niedookreślonej, a więc groźnej grupy politycznej (na przykład ozonowi/wuenerowi wskazali coś...).

7.7. Kolejną właściwością analizowanego materiału jest udział różnych konotacyjnych środków perswazji sięgających po treści ironiczne, aluzyjne, wyzyskiwane najczęściej za pomocą doboru w bliskim sąsiedztwie (w strukturze wyrażenia, połączenia leksykalnego) leksemów o przeciwstawnych znaczeniach, treściach, nacechowanych odmiennie pod względem emotywnym lub aksjologicznym, jak na przykład: górnolotnie wyrodni; kliki wybrańców losu, oślepiać swym martwym blaskiem, wprowadzać zamach $w$ aureoli praw; degenerować się moralnie funkcjami niemoralnymi; mężowie szlachetni aż do obrzydliwości i sprawiedliwi aż do idiotyzmu. W celu wzmocnienia treści ironicznej wielokrotnie stosuje się cudzysłów, na przykład: „błogosławieństwo" 13-letnich rządów sanacji; maskarada „wielkiej i silnej Polski”; emigracyjny „rzad”; „wybitni” spece sanacyjni; prosowiecki „rząd polski” w Kraju.

Bardziej wymowne konteksty ironiczne i aluzyjne ujawniały się w dłuższych zdaniach o charakterze antytezy, jak na przykład: „Maluczka [Armia Ludowa], a wielcy organizatorzy "Armii Ludowej « zapowiedzą nam, że w jej skład wejdą wojska inwazyjne pod dowództwem gen. Eisenhowera!” („Biuletyn Informacyjny” ZWZ/AK 10 lutego 1944 roku); „Tułacze to wojsko zaciężne [armia polska pod dowództwem gen. Z. Berlinga] idzie zza Buga w pompie patriotycznych słów starannie wyreżyserowanego przedstawienia” („Biuletyn Informacyjny” ZWZ/AK 4 czerwca 1944 roku); "Zostaliśmy uroczyście potępieni i wystawiono nam świadectwo niedojrzałości” („Robotnik” WRN 4 czerwca 1944 roku); „W kaście nowoczesnych »wojów « zawodowych [o politykach przedwojennej sanacji] zapanowała bufonada, pobrzękiwanie szabelka i pusty frazes „mocarstwowy” („Żywią i Bronią” marzec 1942 roku). 
Zabiegi perswazyjne służące ośmieszeniu zjawiska, o którym się orzeka, często opierają się na antytezie - jak w przedstawionych dotychczas przykładach — oraz na grach komunikacyjnych, których źródłem, podstawą formalną są:

— znaczenia polisemiczne wyrazów pochodzących z kontekstów semantycznych odległych od świata polityki, na przykład bierzmować - 'przemieniać': „»Lewicowi« sojusznicy sanacyjni, którzy sanatorów na gwałt bierzmuja na demokratów" („Barykada Wolności” 31 stycznia 1942 roku);

- homonimia leksykalna: „P. Bielecki wypowiedział się za utrzymaniem państwa, któreby było skrzyżowaniem demokracji z totalizmem, czyli ukrzyżowaniem demokracji na krzyżu totalizmu” - o koncepcjach politycznych ONR-u („Barykada Wolności" 31 stycznia 1942 roku);

- waloryzacja treści prymarnie negatywnych: „Za swoje akcje organ endecki doczekat się pochwały ze strony prasy hitlerowskiej” („Barykada Wolności” 30 marca $1941 \mathrm{roku})$; „Nasi oficjalni rządcy [rząd londyński] nadal synchronizują swe wyczyny propagandowe z tuba pana Goebbelsa [...] ku uciesze Niemców, hasłami anty-sowieckimi i anty-peperowskimi” („Robotnik” RPPS 16 maja 1944 roku);

— użycie - mniej czy bardziej — dosadnych określeń, powiedzonek: „Oczywiście »Patrioci Polscy«w swej radiostacji Kościuszki klepią [...] Trudno! Pan każe sługa musi” („Biuletyn Informacyjny” ZWZ/AK 20 lipca 1944 roku);

- użycie żartobliwych neologizmów lub derywatów utworzonych od nazw partii, stowarzyszeń politycznych: KRN (Krajowa Rada Narodowa) $\rightarrow$ kran: „»Kran« nie wydawszy z siebie nic prócz dużej porcji wody, już dawno wysechł” („Robotnik” RPPS 1 maja 1944 roku); „Krajowa zd-Rada Narodowa”;

- a przede wszystkim wykorzystanie obrazowego słownictwa w funkcji personifikacji, metonimii czy animizacji: „Po różnych pobrzękiwaniach w swoim gronie pierwsze na światło wystąpiło Stronnictwo Ludowe, bijąc się nieudolnie w piersi za popetniony grzech” („Walka i Wolność” 10 października 1943 roku).

Cały kontekst pragmatyczny wypowiedzi aluzyjnych czy ironicznych, sytuujących się na poziomie szyderczego humoru, zależy oczywiście od więzi komunikacyjnej między nadawcą a odbiorcą wypowiedzi publicystycznej, od ich świadomości językowej czy wrażliwości, kompetencji — zarówno etycznej, jak i estetycznej — gdyż na poziomie środków obrażania pojawiają się nie tylko leksemy nacechowane emotywnie, lecz także pogardliwe, kolokwialne, zaczerpnięte z rejestru potocznego (stary ramol, ciułacz), jak w przykładzie: „Kilkunastu starych ramoli wypycha dolarami materace. Lud polski zażąda kiedyś rachunku [...] Rozrachujemy się wówczas z bezwstydnymi ciułaczami” („Robotnik” 1944, nr 141).

Poza typowymi środkami leksykalnymi występowały również modulanty i operatory metatekstowe pomniejszające znaczenie desygnatu, zjawiska będącego znakiem degradacji (spod znaku, pod szyldem, w rodzaju, rzekomo/rzekomi), por.: 1) spod znaku/pod szyldem/firma + nazwa partii/ugrupowania zbrojnego/obozu politycznego, na przykład: warcholstwo sanacyjne spod znaku Obozu Polski Walczacej, otumanieni robotnicy spod znaku WRN, nowa akcja AK pod nowa firma; 2) w ro- 
dzaju + określenie/nazwa będąca nośnikiem pejoratywnego znaczenia (kontekstowego), na przykład: „machinacje najzacieklejszych faszystów polskich w rodzaju Sosnkowskiego" („Głos Warszawy” 14 marca 1944 roku); „oracje radiowe renegatów w rodzaju Wasilewskiej” („Walka i Wolnośc” 5 grudnia 1943 roku); 3) rzekomy: rzekomi przedstawiciele narodu.

7.8. Inwektywy przyjmujące postać aktu napaści słownej wymierzonej pod adresem wskazanego $\mathrm{z}$ imienia i nazwiska reprezentanta wojennego świata politycznego mają charakter ograniczony. Częściej w materiale źródłowym pojawiają się określenia peryfrastyczne - niekiedy motywowane ironicznie - jak na przykład: bebewuerowska wielkość emigracyjna, okupacyjne wielkości, święta trójca intrygantów emigracyjnych, intrygant emigracyjny pierwszej klasy, sławetni panowie belwederczycy, londyńscy emigranci, którzy swoje cenne osoby ulokowali zapobiegliwie poza zasięgiem okupacji, w londyńskiej wygódce stroją się w pawie piórka. Nie znaczy to, że akty deprecjacji nie mają wymiaru szkalującego - na podstawie opisywanych przykładów można wskazać bardzo pojemny zbiór wyrazów obraźliwych kierowanych często w stronę „obcych” redakcji prasy konspiracyjnej (na przykład płatne pismaki, mocni w gębie, ludzie $z$ Tworek, zgraja pismaków). Wydaje się bowiem, że ograniczony zbiór środków obrażania wskazujących konkretnego polityka wynika z ograniczeń natury pozajęzykowej (sytuacyjnej). Otóż warunki pragmatyczne, a przede wszystkim obowiązująca w redakcjach prasy konspiracyjnej zasada ostrożności komunikacyjnej, czyli zakaz wypowiadania się wprost na temat działaczy politycznych, którzy przebywają w kraju i mogą być - na skutek dekonspiracji - narażeni na represje ze strony niemieckiej policji politycznej (na przykład gestapo), powodowała, że argumenty ad personam dotyczą wyłącznie polityków działających na emigracji, czyli przedstawicieli rządu londyńskiego i reprezentantów przedwojennej sanacji lub polityków działających na terenie ZSRR. Zasadę tę obrazuje fragment dość wyrazistej repliki, donośnej wymiany zdań skierowanej przez redakcję czasopisma lewicowego („Kurier”) do środowisk Związku Walki Zbrojnej (AK):

Któżby się nie wzruszył, czytając te pełne troski i serdeczności słowa [...]. Względy konspiracyjne nie pozwalaja na razie ujawniać nazwisk wysoko uplasowanych zwzetowskich kalumniantów, ani nazwisk osób poszkodowanych, ale my do tego zagadnienia jeszcze niewątpliwie wrócimy. („Kurier” 18 listopada 1943 roku)

Oto kilka bardziej nacechowanych emotywnie lub pogardliwie przykładów inwektyw politycznych:

a) pod adresem Edwarda Rydza-Śmigłego, naczelnego wodza do 1939 roku: „impotent w zakresie organizacji armii”; „manekin w ręce ciemnych sił”; „mały człowiek, wystrychnięty przez klikę [ozonową]”; , awanturnik polityczny, tonący po uszy w kamaszach swego poprzednika [J. Piłsudskiego]” („Naród” październik 1943 roku); ,karzeł z tytułem marszałka” („Barykada Wolności” 23 marca 1941 roku);

b) na temat Ignacego Mościckiego, przedwojennego prezydenta Polski: „stary nimfoman, wsławiony w czasie swego rządcowania chyba tylko kuracją Woronowa, 
uciekając w szwajcarskie zacisze, dokonał sławetnego tryku, który ciąży do dziś nad narodem polskim” („Robotnik” RPPS 26 lipca 1943 roku); „Mościcki ze swoją rozkoszną "tupałką", notoryczny pijak i rozpustnik” („Naród” październik 1943 roku);

c) pod adresem Kazimierza Sosnkowskiego, polityka sanacyjnego w rządzie londyńskim, a po śmierci gen. Władysława Sikorskiego — naczelnego wodza: „osobisty wróg, żywiący ku Sikorskiemu głęboką permanentną nienawiść od czasu Związku Walki Czynnej [...]. Żółć go zalewała, że to nie on, a Sikorski jest naczelnym wodzem [...] naciskał wszelkie sprężyny, żeby tylko poderwać pozycję znienawidzonego konkurenta” („Robotnik” RPPS 26 lipca 1943 roku);

d) deprecjonujących przedstawicieli sanacji - przedwojennych i działających w strukturach władz polskich na uchodźstwie: „Kiedy Bartel z sejmem się dogadali, przyszedł Sławek łamać kości” („Naród” październik 1943 roku); „Marzy się tym kołom generał, który przyjedzie na białym koniu, chwyci lud za mordę i kraj wyda klice na żerowisko” („Barykada Wolności” 23 marca 1941 roku); „Przed czasem uciekli jak szczury z tonącego okrętu” („Żywią i Bronią” kwiecień 1942 roku); „Masy robotnicze sparzyły się raz i dostatecznie na Piłsudskim, by ciągle jeszcze mieć iluzje do takich "pinczerkowych dyktatorków « jak Rydz i Sosnkowski” („Robotnik” RPPS 13 czerwca 1944 roku); „z inspiracji Sosnkowskiego »szurał« zza węgła przeciwko Sosnkowskiemu osławiony monarchista wileński Cat-Mackiewicz" („Robotnik” RPPS 26 lipca 1943 roku);

e) pod adresem polskich działaczy politycznych i wojskowych reprezentujących środowiska komunistyczne w ZSRR: „Wasilewska, kukła pociągana nićmi wielkich reżyserów imperialistycznej polityki sowieckiej” („Żywią i Bronią” 16 czerwca 1944 roku); „pani Wasilewska i pan Berling wraz z wrzaskliwą gromadą "patriotów polskich “ („Żywią i Bronią” 15 kwietnia 1944 roku); „o sprawnego załatwienia się z ludowcami, socjalistami, klerykałami, chłopami, boć wszyscy oni stanowią kontrewolucyjny, psujący powietrze w czystej atmosferze raju sowieckiego" („Szaniec” 4 grudnia 1943 roku); „[Polacy] nie pójdą z podszeptami obcymi, nie pójdą za chociażby najbardziej »hurra " patriotyczną, ale wielką blagą. Naród Polski nie dał się skusić Niemcom, nie pójdzie również na pasku towarzysza pułkownika Berlinga czy Berlingera” („Głos Ludu” 1 grudnia 1943 roku).

Przyjęty - i wydaje się jednomyślnie przestrzegany przez redakcje prasy konspiracyjnej — kodeks życia podziemnego pomniejszał zakres personalnych zaczepek słownych, co nie znaczy, że retoryka sporu była łagodna. Wskazane przykłady ilustrują zarówno napastliwy ton wypowiedzi, jak i szeroki zakres słownictwa pogardliwego, ekspresywnego lub kolokwialnego. Zamiast zaczepek słownych skierowanych do konkretnego adresata inwektywy (czyli polityka, o którym orzeka się wprost) pojawiają się formy wokatywne (dialogowe) sprawiające wrażenie merytorycznej wymiany zdań, a częściej kłótni. Znakiem tej donośnej dyskusji, a jednocześnie retoryki ostrych konfrontacji słownych - sytuacyjnie ograniczonych prawami konspiracji - okazują się komentarze na temat tekstów, poglądów, propozycji politycznych przedstawionych przez stronę przeciwną (najczęściej w systematycznie prowadzonych „przeglą- 
dach prasy przeciwnika"). Pod względem stylistyczno-pragmatycznym charakteryzują się użyciem form wokatywnych, poprzedzonych niekiedy quasi-grzecznościowym zwrotem panowie, na przykład: „Po co taka grandelokwencja, panowie spiskowcy sanacyjni?” („Robotnik” 14 grudnia $1942 \mathrm{roku})$; „Panowie, trochę poczucia humoru!” („Biuletyn Informacyjny” ZWZ/AK 10 lutego 1944 roku).

7.9. Osobnego komentarza wymagają metafory używane w celu degradacji przeciwnika politycznego. Można przyjąć najogólniej, że podstawową dominantą stylistyczną tekstów propagandowych są metafory, metonimiczne frazeologizmy i leksemy zawierające znaczenia konotacyjne (obrazowe), co też znajduje swe odzwierciedlenie w przywołanych już przykładach - analizowanych pod kątem zjawisk strukturalnych, systemowych i semantycznych. W metaforyce politycznej wybija się zarówno konkretny (antropocentryczny), potoczny sposób orzekania o skomplikowanych problemach, jak i - a być może przede wszystkim - skłonność nadawców tekstów propagandowych do ukrywania rzeczywistych intencji komunikacyjnych pod niedosłowną szatą stylistyczną. Ponadto wiele schematów metaforyzacji wniosło do języka komunikacji politycznej rozpoznawalne domeny pojęciowe i rozpoznawalne sposoby ich strukturyzacji ${ }^{13}$.

Akty agresji słownej - a szczególnie inwektywa - bardzo często na poziomie treści (semantyki) czerpią z mechanizmów myślenia potocznego, tym samym poszerzając składniki konotacyjne, analogie i emotywne właściwości pojęć zasługujących - według nadawcy - na potępienie. W inwektywie politycznej wiele jest metaforycznych (metonimicznych) kontekstów zawartych w leksyce odwołującej się do świata zjawisk godnych potępienia ze względu na ich szkodliwość, skrajnie negatywne cechy, wrażenia zmysłowe, estetyczne i emocjonalne (to, co wyjątkowo nieprzyjemne, złe - budzi pogardę, odrazę, a także strach) ${ }^{14}$.

Najpojemniejszą grupę przenośni o zabarwieniu negatywnym (pogardliwym) lub ironicznym (szyderczym) tworzą metafory organiczne, wykorzystujące takie

${ }^{13}$ Więcej na temat metafory politycznej w: I. Kamińska-Szmaj (2007), J. Fras (2006), K. Ożóg (2004), M. Frankowska (1994); o słownictwie metaforycznym zawierającym odniesienia do pojęć będących podstawą aktu agresji słownej także w: M. Peisert (2004), J. Wasilewski (2006). Natomiast na temat związków metaforycznych związanych z domeną „wojna-polityka” w: J. Pacuła (2012), M. Fabiszak (2007), Połowniak-Wawrzonek (2008), G. Lakoff (2003) itp.

${ }^{14}$ Metafora jest również - z perspektywy agensa aktu obrażania - funkcjonalnym środkiem stylistycznym, gdyż często nie wskazuje wprost zjawisk, obiektów, subiektów, adresatów napaści słownej, a jedynie wywołuje nieprzyjemne wrażenia zmysłowe, emocjonalne, a co więcej, akt wypowiedzi szkalującej tworzy za pomocą znaczeń konotacyjnych (czyli nie mówi wprost o tym, co pomniejsza/ szkaluje, ale dobierając wyraziste leksemy same w sobie nazywające negatywne zjawiska, wprowadza taki kontekst). Szczególnie oddziałuje poprzez antropocentryczny sposób kategoryzowania świata (zjawiska zagrażające, potępiane ujmowane są często w odniesieniu do świata biologicznego, przyrodniczego, zwierzęcego, organicznego, wyobrażeń na temat bytów transcendentnych, stereotypów potocznych/ludowych). Wiele $\mathrm{z}$ nich ma charakter uniwersalny, nawet skliszowany ('polityka jako wojna, teatr, rozrywka, gra, hazard, choroba, (od)budowa' itp.), ujęty w struktury odzwierciedlające aksjologiczne składniki/oś wartościowania (oś wartościowania: 'góra-dół, prawo-lewo, przeszłośćprzyszłość, światłość-ciemność, noc-dzień’ itp.; por. na przykład Język w kręgu... 2003, Tokarski 2013). 
nośniki antywartości, jak bagno, zgnilizna, rozkład. Niekiedy służą one ekspozycji "antywartości” zderzających się z typową dla propagandy wojennej konceptualizacją państwa, społeczeństwa jako organizmu (organizm społeczny, żywe ciało narodu) (por. Wolińska 1992; Mazur 2011). Na pograniczu tej domeny pojawiają się znaczenia przenośne, wykorzystujące metaforykę choroby, przy czym za pomocą nośników odwołujących się do potocznych określeń ran, nowotworów i epidemii (wrzód, gangrena, nowotwór) deprecjonuje się świat przypisywany przeciwnikowi politycznemu, a szczególnie jego działania uznawane za groźne (jad, trucizna, zaraza).

Szukając wyrazistych porównań i asocjacji mających wyostrzyć obraz przeciwnika/wroga jako odpowiedzialnego za kryzys/konflikt polityczny, postępującego wbrew prawu, naruszającego polską rację stanu, redaktorzy prasy konspiracyjnej wykorzystują metaforykę przestępczą i metaforykę hazardu, a działania polityczne uznane za zagrażające, antagonistyczne, konfliktotwórcze przestawiają za pomocą metafory militarnej. Co ciekawe, na tle wydarzeń wojennych aktualizuje się znany schemat pojęciowy 'polityka to wojna', lecz za pomocą słownictwa militarnego (manewry, storpedować), czyli odnoszącego się nie tyle do stanu wojny w sensie ogólnym, ile do konkretnych desygnatów związanych z realiami konfliktu zbrojnego - kontekstu sytuacyjnego, doświadczeń codziennych, w którym powstaje tak zmetaforyzowana wypowiedź.

Na pograniczu tych najważniejszych nośników stoją typowe dla języka polityki domeny pojęciowe, służące ironicznej, prześmiewczej degradacji działań, zachowań propagandowych uznawanych za nadmiernie widowiskowe, a przez to śmieszne w tym celu wykorzystuje się często metaforę teatru (cyrku) i sportu.

Ponieważ szczegółowa analiza skomplikowanych zjawisk konceptualnych wykraczałaby z pewnością poza ramy tego artykułu, najważniejsze przykłady znaczeń przenośnych wykorzystywanych w funkcji inwektywy i wartościowania negatywnego przeciwnika politycznego - wraz z próbą interpretacji — zestawiam w tabeli. 


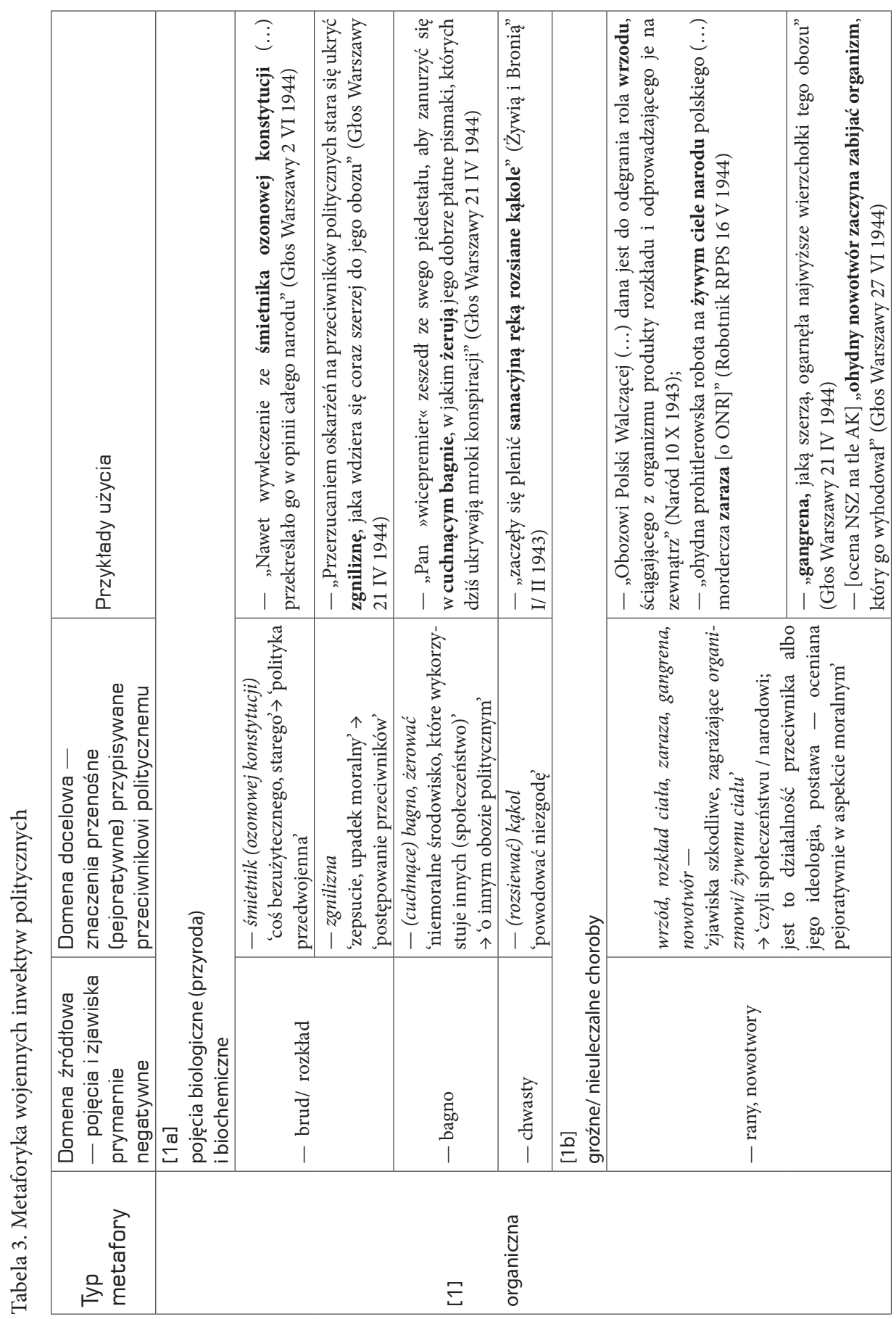




\begin{tabular}{|c|c|c|c|c|}
\hline 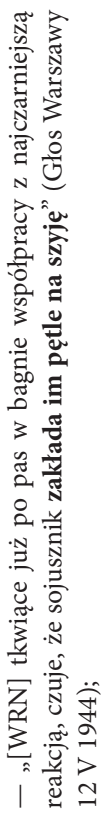 & 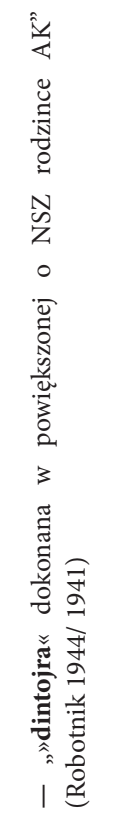 & 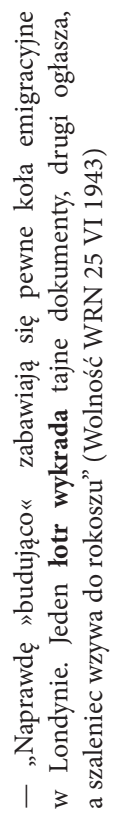 & 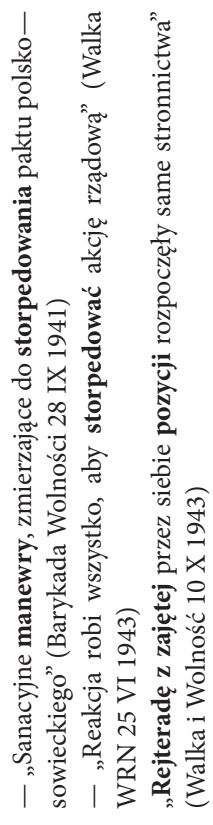 & 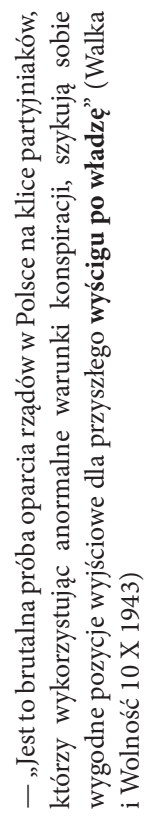 \\
\hline 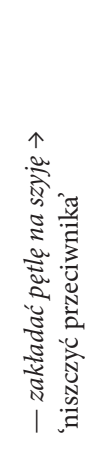 & 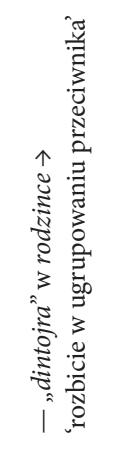 & 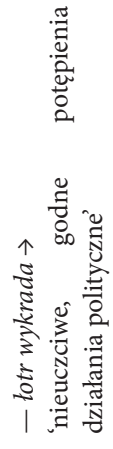 & 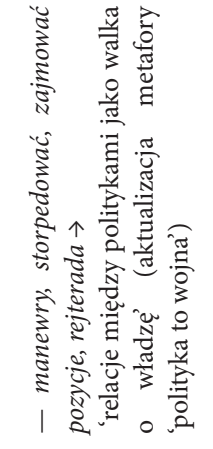 & 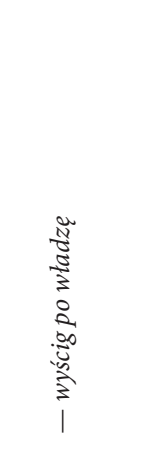 \\
\hline 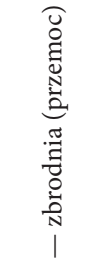 & 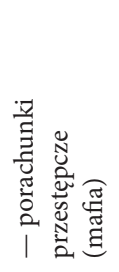 & $\begin{array}{c}\frac{0}{3} \\
\frac{2}{\pi} \\
\frac{N}{0} \\
\frac{0}{N} \\
1\end{array}$ & 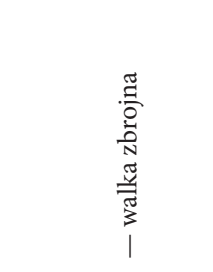 & 总 \\
\hline & 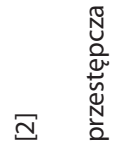 & & 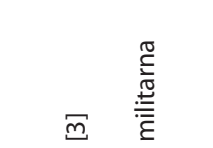 & 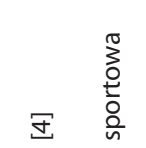 \\
\hline
\end{tabular}




\begin{tabular}{|c|c|c|}
\hline 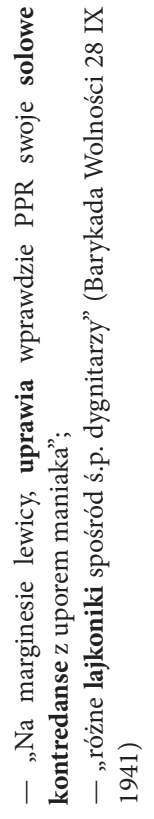 & 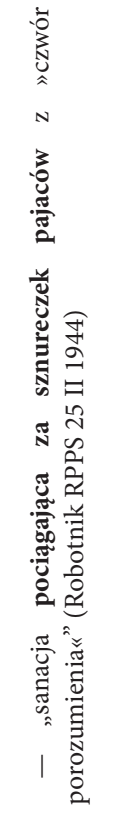 & 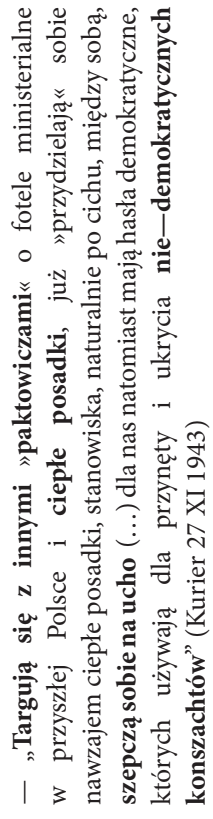 \\
\hline 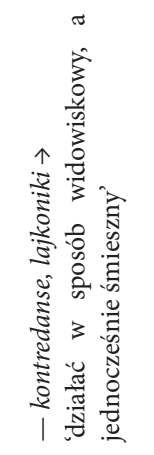 & 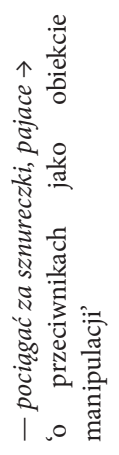 & 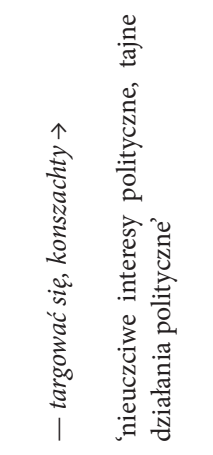 \\
\hline 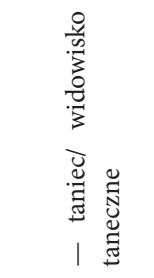 & 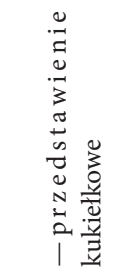 & 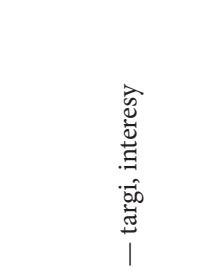 \\
\hline 离 & & 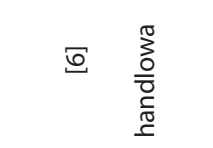 \\
\hline
\end{tabular}


Kończąc te rozważania, warto dopowiedzieć, że im bardziej w tekstach czytelne okazują się intencje szkalowania czy zniesławiania rywala politycznego, tym częściej też w jednej wypowiedzi kondensują się różne typy metafor, niekiedy przyjmując postać hiperboli. Nagromadzeniu ulegają leksemy wywodzące się z domen pojęciowych wskazujących groźne lub nieprzyjemne zjawiska biologiczne, przyrodnicze (na przykład potwór, hydra, jad, odór, rozkład, bagno, wrzód, nowotwór, gangrena, zaraza, trucizna, trup, gnojówka). Taki antropocentryczny, emotywny, a jednocześnie napastliwy styl polemiki politycznej ilustrują następujące przykłady: „Na to trzeba tak głębokiego zgangrenowania, tak cuchnącego rozkładu, jaki ujawnia w chwili obecnej cały obóz reakcyjny, zatruwający ohydnym odorem życie społeczne Polski” („Głos Warszawy” 27 czerwca 1944 roku); „Kierownicze sfery reakcji $\mathrm{w}$ walce z przeciwnikami politycznymi chwytają się metod najbardziej plugawych, jakie zdoła wymyślić ludzka nikczemność. Skrytobójczy cios, denuncjacja na gestapo [...] Nie ma tak cuchnącej gnojówki, w którejby nie nurzali swych piór reakcyjne pismaki” („Głos Warszawy” 19 listopada 1943 roku).

W niektórych kontekstach można zaobserwować nie tylko hiperbolizację zjawisk podlegających krytyce, lecz także porównania metaforyczne, amalgamaty pojęciowe, które polegają na zastępowaniu jednych pojęć przenośnych innymi, aby pogłębić obraz zjawiska wskazanego przez nadawcę. Spójrzmy na kilka przykładów: "Te mafie i kliki, zamaskowane niejednokrotnie czerwonym kapturem, to nic innego tylko zielsko wyrosłe na gruzach” („Barykada Wolności” 15 lutego 1942 roku); „Proces rodzenia się Polskiego Frontu Ludowego przebiega jak każdy poród w bólach i troskach” („Robotnik” RPPS 1 maja 1944 roku). Dopowiedzieć należy, że w funkcji licznych animizacji czy personifikacji pojęć politycznych, działań, ogólnie rzecz biorąc - rzeczywistości utożsamianej z rywalem politycznym, pojawia się przeogromny zbiór leksemów, związków wyrazowych odwołujących się do świata zwierzęcego, mitologicznego (hydra, głowonóg), transcendentnego (duch, upiór). Akty deprecjacji sytuują się na pograniczu komunikacji pogardliwej i humorystycznej (ironicznej): „Chodzi o to, ażebyśmy jak zahipnotyzowany ptak wpadli bez próby nawet oporu w objęcia boa dusiciela” („Naród” luty 1943 roku); „Sanacja przepoiła sobą całe życie w konspiracji i niczym złowróżebny upiór czyha na władzę w Polsce powojennej” („Walka i Wolność” 1 listopada 1943 roku); „[Rada Jedności Narodowej] chata na kurzej nóżce, w której straszy duch sanacji” („Głos Warszawy” 30 czerwca 1944 roku).

\section{Podsumowanie}

Jak wynika z zaprezentowanych analiz, językowe środki perswazji w tekstach propagandowych lat 1939-1945 są niezwykle impresywne, obrazowe i uwikłane w różne znaczenia kontekstowe (konotacyjne). Wracają w nich wzorce dawnych, propagandowych strategii zachowań językowych (por. Kamińska-Szmaj 1994; Polkowska 
2015; Karamańska 2007). Język wypowiedzi polemicznych odzwierciedla zaś konflikty realne i pęknięcia na scenie politycznej, głównie w obrębie dwóch nurtów życia politycznego i wojskowego (prorządowego i antyrządowego). Wielokrotnie przeciwnika opisuje się w podobny sposób jak wroga zewnętrznego (okupanta), a co najmniej określa etykietkami, które mogą wywoływać takie konotacje. Podstawą wielu asocjacji są konteksty, w których umieszcza się epitety wartościujące negatywnie w grupach leksykalnych odnoszących się do świata ideologii hitlerowskiej (faszystowskiej), a także stalinizmu (bolszewizmu), nadając tym wyrazom nowe w stosunku do ich przedwojennych użyć - znaczenia (por. Dubisz 2007; Jaeschke 2002; Karamańska 2007).

Okazuje się, że wiele obraźliwych określeń - szczególnie dotyczących rządów przedwojennych i działalności władz polskich na uchodźstwie - znajdzie swoją kontekstualną realizację w języku propagandy politycznej okresu PRL-u (por. Nowak 2002; Dytman-Stasieńko 2006).

Komunikacja polityczna lat 1939-1945, wykorzystująca mechanizmy agresji słownej, miała również swoją odmienną stylistykę. Posługiwano się nie tylko językowymi środkami walki z wrogiem politycznym, lecz także retoryką zawierającą liczne pozytywne hasła życia społecznego, obywatelskiego w przyszłej, odrodzonej Polsce. Retoryka ta, zapożyczająca podniosłe motywy i toposy, wymaga jednak oddzielnego opracowania (por. Wolińska 1996).

\section{Literatura przedmiotu}

Bartmiński J. (2006): Językowe podstawy obrazu świata, Lublin.

Bartoszewski W. (1987): 1859 dni Warszawy, Warszawa.

Bartoszewski W. (1987): Na drodze do niepodległości, Paryż.

Brzoza Cz., Sowa A.L. (2009): Historia Polski 1918-1945, Kraków.

Cała A. (2012:) Żyd - wróg odwieczny? Antysemityzm w Polsce i jego źródła, Warszawa.

Cegieła A. (2014): Słowa i ludzie. Wprowadzenie do etyki słowa, Warszawa.

Chlebda W. (2007): Kiedy swój staje się obcym, „Etnolingwistyka” nr 19.

Chrobaczyński J. (2012): Dramatyczny rok 1943. Postawy i zachowania społeczeństwa polskiego w rozstrzygającym roku II wojny światowej, Rzeszów-Kraków.

Chrobaczyński J. (2015): Konteksty przełomu 1944-1945. Społeczeństwo wobec rozstrzygnięć. Postawy - zachowania - nastroje, Kraków.

Cytowska E. (1986): Szkice z dziejów prasy pod okupacją niemiecka (1939-1945), Warszawa-Łódź.

Czyżewski M. (2007): „Język wrogości” oraz spór o III i IV RP w perspektywie analizy dyskursu publicznego. Wybrane rezultaty projektu badawczego oraz uwagi metodologiczne, [w:] Język IV Rzeczypospolitej, red. M. Czerwiński, P. Nowak, R. Przybylska, Lublin.

Dijk van T.A. (2002): Dyskurs polityczny i ideologia, „Etnolingwistyka” nr 15.

Dobek-Ostrowska B. (2004): Media masowe i aktorzy polityczni w świetle studiów nad komunikowaniem politycznym, Wrocław.

Dubisz S. (2007): Przekształcenia znaczeniowe słownictwa społeczno-politycznego $w$ polszczyźnie XIX i XX (analiza danych leksykograficznych), [w:] Lingwistyka a polityka. Słownik pojęć politycznych i społecznych krajów Europy Srodkowej $i$ Wschodniej, red. S. Dubisz, J. Porayski-Pomsta, E. Sękowska, Warszawa. 
Dytman-Stasieńko A. (2006): Święto zawłaszczonych znaczeń. 1 Maja w PRL. Ideologia, rytuał, język, Wrocław.

Fabiszak M. (2007): A Conceptual Metaphor Approach to War Discourse and its Implications, Poznań. Frankowska M. (1994): Frazeologia i metaforyka w tekstach politycznych lat 1989-1993, [w:] Język a kultura, t. 9, red. J. Anusiewicz, B. Siciński, Wrocław.

Fras J. (2006): Komunikacja polityczna. Wybrane zagadnienia gatunków i języka wypowiedzi, Wrocław. Garlicki J., Noga-Bogomilski A. (2004): Kultura polityczna w społeczeństwie obywatelskim, Warszawa. Głowińki M. (1990): Nowomowa po polsku, Warszawa.

Głowiński M. (1995): Mowa i zło, [w:] idem, Pismak 1986 i inne szkice o różnych brzydkich rzeczach, Warszawa.

Głowiński M. (1996): O dyskursie totalitarnym, [w:] O zagrożeniach i bogactwie polszczyzny, red. J. Miodek, Wrocław.

Głowiński M. (2002): Mowa agresji, [w:] Człowiek i agresja. Głosy o nienawiści i przemocy. Ujęcie interdyscyplinarne, red. S. Amsterdamski, Warszawa.

Głowiński M. (2007): Retoryka nienawiści, „Nauka” nr 2.

Głowiński T. (2000): O nowy porządek europejski. Ewolucja hitlerowskiej propagandy politycznej wobec Polaków w Generalnym Gubernatorstwie 1939-1945, Wrocław.

Golka B. (1975): Prasa konspiracyjna ruchu ludowego, Białystok.

Greń Z. (1994): Semantyka i składnia czasowników oznaczających akty mowy w języku polskim, Warszawa.

Grzmil-Tylutki H. (2011): Francuska lingwistyczna teoria dyskursu. Historia, tendencje, perspektywy, Kraków.

Habielski R. (2009): Polityczna historia mediów w Polsce w XX wieku, Warszawa.

Howarth D. (2008): Dyskurs, przeł. A. Gąsior-Niemiec, Warszawa.

Ignatowicz A. (2011): Formy i metody oddziaływania propagandowego Armii Krajowej na społeczeństwo polskie w drugiej połowie 1943 roku, [w:] Komunikowanie się Polaków w okresie II wojny światowej, red. K. Stępnik, M. Rajewski, Lublin.

Jaeschke A. (2002): Totalni sąsiedzi Polski w publicystyce politycznej 1931-1939, Kraków.

Jarecka U. (2008): Propaganda wizualna słusznej wojny. Media wizualne XX wieku wobec konfliktów zbrojnych, Warszawa.

Jarecka U. (2010): Propaganda stusznej wojny, Warszawa.

Jarowiecki J. (1980a): Konspiracyjna prasa w Krakowie w latach okupacji hitlerowskiej 1939-1945, Kraków.

Jarowiecki J. (1980b): Prasa w Polsce 1939-1945, [w:] Prasa polska 1939-1945, red. J. Łojek, Warszawa. Jastrzębski Z. (1986): Poetyka humoru lat okupacji, Warszawa.

Jędrzejko E. (1996): Język satyry okupacyjnej, [w:] Język polski czasu drugiej wojny światowej (19391945), red. I. Bajerowa, Warszawa.

Język polski czasu drugiej wojny światowej (1996): red. I. Bajerowa, Warszawa.

Język w kręgu wartości (2003): red. J. Bartmiński, Lublin.

Kaczmarek R. (2010): Historia Polski 1914-1989, Warszawa.

Kamińska-Szmaj I. (1994): Judzi, zohydza, ze czci odziera. Język propagandy politycznej w prasie 19191923, Wrocław.

Kamińska-Szmaj I. (2007): Agresja językowa w życiu publicznym. Leksykon inwektyw politycznych 1918-2000, Wrocław.

Kamińska-Szmaj I. (2011): Język polityki czy styl/dyskurs polityczny, [w:] Dyskursy trzeciego tysiaclecia, red. E. Pajewska, Szczecin.

Kamińska-Szmaj I. (2013): Komunikacja polityczna - język, styl, dyskurs, [w:] Style współczesnej polszczyzny. Przewodnik po stylistyce polskiej, red. E. Malinowska, J. Nocoń, U. Żydek-Bednarczuk, Opole. 
Kamińska-Szmaj I. (2014): Zdobywanie władzy - zawłaszczanie języka (akcje propagandowe poprzedzające powstanie PRL), [w:] Oblicza Komunikacji 7. Język polityki - historia i współczesność, red. I. Kamińska-Szmaj, T. Piekot, M. Poprawa, Wrocław.

Kamińska-Szmaj I. (2016): U źródeł politycznego dyskursu dominującego w czasach PRL, [w:] Dyskurs i jego odmiany, red. B. Witosz, K. Sujkowska-Sobisz, E. Ficek, Katowice.

Kampka A. (2014): Debata publiczna. Zmiany społecznych norm komunikacji, Warszawa.

Karamańska M. (2007): Słownictwo polityczne drugiej Rzeczypospolitej w latach 1926-1939, Kraków.

Karwat (2014): Podstawy socjotechniki dla politologów, polityków i nie tylko, Warszawa.

Karwat M. (2006): O złośliwej dyskredytacji. Manipulowanie wizerunkiem przeciwnika, Warszawa.

Kleszczowa K. (1996): Odbicie rzeczywistości wojennej i okupacyjnej w leksyce języka ogólnego, [w:] Język polski czasu drugiej wojny światowej (1939-1945), red. I. Bajerowa, Warszawa.

Kleszczowa K. (1996a): Sytuacja języka polskiego w Generalnej Guberni, [w:] Język polski czasu drugiej wojny światowej (1939-1945), red. I. Bajerowa, Warszawa.

Kłosińska K. (2012): Etyczny i pragmatyczny. Polskie dyskursy polityczne po 1989 roku, Warszawa.

Kłosińska K. (2016): Opozycja jako podstawowe tworzywo dyskursów politycznych, [w:] Dyskurs i jego odmiany, red. B. Witosz, K. Sujkowska-Sobisz, E. Ficek, Katowice.

Kochan M. (1994): „Przyklejanie etykietek”, czyli o negatywnym określaniu przeciwnika, [w:] Język a kultura, t. 9, red. J. Anusiewicz, B. Siciński, Wrocław.

Kochan M. (2006): Pojedynek na słowa. Techniki erystyczne w publicznych sporach, Kraków.

Komunikowanie się Polaków w okresie II wojny światowej (2011): red. K. Stępnik, M. Rajewski, Lublin.

Korboński S. (2008): Polskie Państwo Podziemne. Przewodnik po Podziemiu z lat 1939-1945, Warszawa.

Kövecses Zoltán (2006): Język - umysł - kultura. Praktyczne wprowadzenie, przeł. A. Kowalcze-Pawlik, M. Buchta, Kraków.

Kowalski S., Tulli M. (2003): Zamiast procesu. Raport o mowie nienawiści, Warszawa.

Kudra B. (2001): Kreatywność leksykalna $w$ dyskursie politycznym polskiej prasy lat osiemdziesiątych i dziewięćdziesiątych, Łódź.

Kunert A.K. (1996): Ilustrowany przewodnik po Polsce Podziemnej 1939-1945, Warszawa.

Lakoff G. (2003): Metafory i wojna. System metafor użyty, by usprawiedliwić wojnę w Zatoce Perskiej, „Etnolingwistyka”.

Lewandowska S. (1992): Prasa okupowanej Warszawy 1939-1945, Warszawa.

Linde-Usiekniewicz J. (2015): Teoria relewancji jako narzędzie opisu „mowy nienawiści”, „Studia Pragmalingwistyczne" R. 7.

Mackiewicz (Cat) S. (1993): Historia Polski od 17 września 1939 r. do 5 lipca 1945 r., London.

Małyska A. (2012): Strategie komunikacyjne we współczesnym dyskursie politycznym, Lublin.

Mazur M. (2011): Język polityki PPR podczas II wojny światowej, [w:] Komunikowanie się Polaków w okresie II wojny światowej, red. K. Stępnik, M. Rajewski, Lublin.

Michlic J.B. (2015): Obcy jako zagrożenie. Obraz Żyda w Polsce od 1890 roku do czasów obecnych, Warszawa.

Nowak P. (2002): SWÓJ i OBCY w językowym obrazie świata. Język publicystyki polskiej z pierwszej połowy lat pięćdziesiątych, Lublin.

Nowak P. (2007): Opozycja „swój-obcy” a skuteczność komunikacji. Wybrane zagadnienia, „Etnolingwistyka" nr 19.

Nowak P. (2008): Retoryka a propaganda polityczna, [w:] Retoryka, red. M. Barłowska, A. Budzyńska-Daca, P. Wilczek, Warszawa.

Olszyk S. (2013): Stereotyp wroga $w$ walce wyborczej w Polsce, Olsztyn.

Ostaszewska D. (1996): Wplywy rosyjskie i ukraińskie, [w:] Język polski czasu drugiej wojny światowej (1939-1945), red. I. Bajerowa, Warszawa.

Ożóg K. (2004): Język w stużbie polityki, Rzeszów.

Ożóg K. (2014): Rytualizacja w języku władzy komunistycznej PRL, [w:] Oblicza Komunikacji 7. Język polityki - historia i współczesność, red. I. Kamińska-Szmaj, T. Piekot, M. Poprawa, Wrocław. 
Pacuła J. (2012): Słowa w natarciu. Metaforyka militarna w dyskursie publicznym, „Zeszyty Prasoznawcze" nr 3.

Pajdzińska A. (2008): O nepotyzmie, kumoterstwie i kolesiostwie słów kilka, „Etnolingwistyka” nr 20.

Peisert M. (2004): Formy i funkcje agresji werbalnej. Próba typologii, Wrocław.

Polkowska L. (2015): Język prawicy, Warszawa.

Połowniak-Wawrzonek D. (2008): Związki frazeologiczne współczesnego języka polskiego motywowane sytuacją walki (zbrojnej), Kielce.

Poprawa M. (2012): Badania nad dyskursem we współczesnym językoznawstwie polonistycznym, [w:] Oblicza Komunikacji 5. Analiza dyskursu: centrum-peryferie, red. I. Kamińska-Szmaj, T. Piekot, M. Poprawa, Wrocław.

Reisigl M. (2010): Dyskryminacja w dyskursach, „Tekst-Dyskurs” nr 3.

Reykowski J. (1984): Logika walki, Warszawa.

Reykowski J. (2002): Konflikty polityczne, [w:] Psychologia polityczna, red. K. Skarżyńska, Warszawa.

Riesigl M. (2010): Dyskryminacja w dyskursach, przeł. D. Przepiórkowska, „Tekst i Dyskurs - Text und Diskurs" nr 3.

Rittel S.J. (2003): Komunikacja polityczna. Dyskurs polityczny. Język w przestrzeni politycznej, Kielce.

Sarnowski M. (1999): Przestrzeń komunikacji negatywnej w języku polskim i rosyjskim, Wrocław.

Skarżyńska K. (2001): Jak porozumiewają się politycy: język ostrych kategoryzacji; psychologiczne przyczyny i konsekwencje, [w:] Zmiany w publicznych zwyczajach językowych, red. J. Bralczyk, K. Mosiołek-Kłosińska, Warszawa.

Szarota T. (2010/1988): Okupowanej Warszawy dzień powszedni, Warszawa.

Śpiewak P. (2012): Żydokomuna. Interpretacje historyczne, Warszawa.

Taras B. (2013): Agresja. Studium semantyczno-pragmalingwistyczne, Rzeszów.

Tokarski J. (2013): Światy między słowami. Wprowadzenie do semantyki językowej, Lublin.

Warchala J. (2016): O pewnych warunkach perswazji, „Artes Humanae” vol. 1.

Wasilewski J. (2006): Retoryka dominacji, Warszawa.

Wasilewski J. Skibiński A. (2008): Prowadzeni słowami. Retoryka motywacji w komunikacji publicznej, Warszawa.

Winstone M. (2015): Generalne Gubernatorstwo. Mroczne serce Europy Hitlera, przeł. T. Fiedorek, Poznań.

Witosz B. (2009): Dyskurs i stylistyka, Katowice.

Witosz B. (2010): O dyskursie wykluczenia i dyskursach wykluczajacych z perspektywy lingwistycznej, „Tekst i Dyskurs - Text und Diskurs” nr 3.

Wolińska O. (1992): Nowomowa a język propagandy wojennej, „Postscriptum” nr 5.

Wolińska O. (1996): Język polski w walce, [w:] Język polski czasu drugiej wojny światowej, red. I. Bajerowa, Warszawa.

Woźniakowski K. (2014): Polskojęzyczna prasa gadzinowa czasów okupacji hitlerowskiej, Kraków.

Zimny R., Nowak P. (2009): Słownik polszczyzny politycznej po roku 1989, Warszawa.

\section{Invectives of the Second World War period. Linguistic means of insulting political opponents/enemies in the underground press of 1939-1945}

Summary

The author of the article examines strategies used to belittle political opponents in the underground press published in Poland in 1939-1945. It turns out that the language of political propaganda in the period had many communication strategies employed in the fight against political rivals, often 
regarded as enemies. The author presents examples of how political invectives were used in a very important period of power struggle among political parties operating in the underground.

Keywords: wartime political discourse, political propaganda, wartime propaganda, language of political propaganda of the Second World War, political invective. 